WIDER Working Paper 2021/4

The role of automatic stabilizers and emergency tax-benefit policies during the COVID-19 pandemic in Ecuador

H. Xavier Jara, ${ }^{1}$ Lourdes Montesdeoca, ${ }^{2}$ and Iva Tasseva ${ }^{3}$

January 2021 
Abstract: This paper makes use of tax-benefit microsimulation techniques to quantify the distributional effects of COVID-19 in Ecuador and the role of tax-benefit policies in mitigating the immediate impact of the economic shocks. Our results show a dramatic increase in income poverty and inequality between December 2019 and June 2020. The poverty rate, measured with the national poverty line, goes up from 25.7 to 58.2 per cent over this period and extreme poverty increases from 9.2 to 38.6 per cent. Inequality measured by the Gini coefficient increases substantially from 0.461 to 0.592 . On average, household disposable income drops by 41 per cent. The new Family Protection Grant provides income protection for the poorest income decile. However, overall tax-benefit policies do little to mitigate the losses in household incomes due to the pandemic.

Key words: COVID-19, microsimulation, poverty, inequality, Ecuador

JEL classification: D31, E24, H24

Acknowledgements: The results presented here are based on ECUAMOD v1.5. ECUAMOD is developed, maintained, and managed by UNU-WIDER in collaboration with the EUROMOD team at ISER (University of Essex), SASPRI (Southern African Social Policy Research Insights), and local partners in selected developing countries (Ethiopia, Ghana, Mozambique, Tanzania, Uganda, Zambia, Ecuador, and Viet Nam) in the scope of the SOUTHMOD project. The local partner for ECUAMOD is Facultad Latinoamericana de Ciencias Sociales (FLACSO) Sede Ecuador. We are indebted to the many people who have contributed to the development of SOUTHMOD and ECUAMOD, particularly all past members of the previous local partner for ECUAMOD, Instituto de Altos Estudios Nacionales (IAEN): César Amores, Mauricio Cuesta, Pablo Garcés, Po Chun Lee, and Marcelo Varela. We would like to thank Jesse Lastunen, Fernando Martin, Pia Rattenhuber, Kunal Sen, Holly Sutherland, and Leonardo Vera for their valuable comments and suggestions. The results and their interpretation presented in this publication are solely the authors' responsibility.

\footnotetext{
${ }^{1}$ Institute for Social and Economic Research, University of Essex, Colchester, UK, corresponding author: hxjara@essex.ac.uk, ${ }^{2}$ Facultad Latinoamericana de Ciencias Sociales (FLACSO) Sede Ecuador, Quito, Ecuador, ${ }^{3}$ Department of Social Policy, London School of Economics and Political Science, London, UK

This study has been prepared within the UNU-WIDER project SOUTHMOD - simulating tax and benefit policies for development Phase 2, which is part of the Domestic Revenue Mobilization programme. The programme is financed through specific contributions by the Norwegian Agency for Development Cooperation (Norad).

Copyright (C) UNU-WIDER 2021
}

UNU-WIDER employs a fair use policy for reasonable reproduction of UNU-WIDER copyrighted content—such as the reproduction of a table or a figure, and/or text not exceeding 400 words - with due acknowledgement of the original source, without requiring explicit permission from the copyright holder.

Information and requests: publications@wider.unu.edu

ISSN 1798-7237 ISBN 978-92-9256-938-9

https://doi.org/10.35188/UNU-WIDER/2021/938-9

Typescript prepared by Lesley Ellen.

United Nations University World Institute for Development Economics Research provides economic analysis and policy advice with the aim of promoting sustainable and equitable development. The Institute began operations in 1985 in Helsinki, Finland, as the first research and training centre of the United Nations University. Today it is a unique blend of think tank, research institute, and UN agency — providing a range of services from policy advice to governments as well as freely available original research.

The Institute is funded through income from an endowment fund with additional contributions to its work programme from Finland, Sweden, and the United Kingdom as well as earmarked contributions for specific projects from a variety of donors.

Katajanokanlaituri 6 B, 00160 Helsinki, Finland

The views expressed in this paper are those of the author(s), and do not necessarily reflect the views of the Institute or the United Nations University, nor the programme/project donors. 
In addition to the devasting public health emergency worldwide, the COVID-19 pandemic has resulted in an international crisis which is likely to affect vulnerable population groups more than others as a result of the effects of lockdown and social distancing policies in the short term and the negative effect on employment and earnings in the long term. The COVID-19 outbreak is therefore reinforcing inequalities, and the depth of this effect is likely to be more severe in already highly unequal societies such as in Latin America.

According to estimates from the Economic Commission for Latin America and the Caribbean (ECLAC) (ECLAC 2020b) a contraction of -9.1 per cent of gross domestic product (GDP) and an increase of 5.4 percentage points in unemployment is expected by the end of 2020 in Latin America. Contrary to developed economies, Latin American countries lack fiscal capacity and offer limited social protection, which represents an important challenge to cope with the socioeconomic effects of the crisis. Ecuador is one of the countries in the region that has been the most severely affected by the COVID-19 outbreak. As of 15 July 2020, Ecuador had reported 61,373 coronavirus cases and a total number of 5,158 deaths due to the virus, making it one of the countries with the largest number of deaths per million people in Latin America (WHO 2020). Moreover, these official figures may underestimate the magnitude of the health crisis, as the total number of deaths from all causes has soared in certain parts of the country compared to statistics before the COVID19 outbreak. ${ }^{1}$ The economic cost of the crisis is also likely to be large in Ecuador, as oil prices (the country's main source of revenue) were already low prior to the pandemic and plummeted as a result of the crisis.

As a response to the crisis, governments in Latin America have implemented a variety of social protection measures such as cash and in-kind transfers, provision of basic services, and tax reliefs. The coverage and generosity of the emergency measures vary widely across countries. The main policy implemented by the Ecuadorian government is the health emergency Family Protection Grant (Bono de Protección Familiar), which offers a US\$120 transfer to low-income families. The transfer, however, excludes individuals in receipt of other social cash transfers and no additional payments have been offered to beneficiaries of the main social assistance scheme, the Human Development Transfer (Bono de Desarrollo Humano). Additionally, as a result of the crisis, the Ecuadorian government has opted for austerity packages, such as salary cuts for public sector workers and a reduction of expenditures in education, which could have long-term consequences. The crisis and the policy response from the Ecuadorian government are therefore likely to affect the living standards and long-term opportunities of vulnerable populations in the country.

The aim of this paper is to investigate the role of tax-benefit policy interventions in mitigating the socioeconomic effects of COVID-19 in Ecuador. More precisely, we compare the pre-COVID situation based on household survey data from December 2019 with a COVID scenario derived by adjusting the 2019 data to capture the effect of the pandemic on the labour market and earnings based on household survey data collected by the National Statistical Institute in May/June 2020. Our COVID scenario, thus, captures the effect of lockdown measures in place until May 2020,

\footnotetext{
${ }^{1}$ On 16 April 2020, the Financial Times reported that between 1 March and 15 April 15 of this year, just 245 official COVID-related deaths were reported in the Guayas province, but data on total deaths showed that the total number of people who died during this period increased by 350 per cent compared to a typical year. See Burn-Murdoch et al. 2020). The National Civil Registry reports an excess of more than 10,000 deaths from March to May 2020, compared to the same period in previous years (DNRCIC 2020).
} 
which were progressively relaxed during the month of June 2020. Then, we use ECUAMOD, the tax-benefit microsimulation model for Ecuador, and follow a decomposition approach to quantify the distributional effects of: (i) earnings losses due to COVID-19, (ii) pre-crisis tax-benefit policies (i.e. automatic stabilizers), and (iii) COVID-related tax-benefit measures implemented by the government. The decomposition method used in the paper builds on work by Bargain and Callan (2010), extended by Paulus and Tasseva (2020) and recently applied to the context of the COVID19 crisis in the UK by Brewer and Tasseva (2020).

Our results show a dramatic increase in poverty and inequality between December 2019 and June 2020 due to the COVID-19 pandemic. Poverty increases by 32.5 percentage points, bringing 58.2 per cent of the population below the national poverty line compared to 25.7 per cent in December $2019 .^{2}$ Extreme poverty increases by 29.4 percentage points (from 9.2 to 38.6 per cent) and inequality by 0.131 percentage points ( 0.461 to 0.592$)$ measured by the Gini coefficient. On average, household disposable income drops sharply by 41 per cent. The impact is larger in the middle of the income distribution with a U-shaped pattern in the change of mean household disposable income, which is related to the distribution of earners in different industries across the income distribution and is consistent with recent findings for other Latin American countries (Lustig et al. 2020). Our decomposition shows that, on average, automatic stabilizers and COVIDrelated policies will provide very limited income protection. The effect of automatic stabilizers on household disposable incomes is larger than that of COVID-related benefits, and their effects vary across the income distribution. The contribution of automatic stabilizers, in particular social insurance contributions (SICs) and personal income tax, increases towards the top of the income distribution, i.e. they mitigate the losses in gross earnings of higher-income families more than of lower-income families. The COVID-related Family Protection Grant provides larger protection to households at the bottom of the distribution but plays a limited role in reducing poverty and inequality.

Our analysis contributes to the growing literature assessing the role of tax-benefit policies in mitigating the distributional impact of the COVID-19 pandemic (Beirne et al. 2020; Brewer and Tasseva 2020; Bronka et al. 2020; Figari and Fiorio 2020; Lustig et al. 2020). The topic is of particular relevance to developing countries in that it provides evidence about the additional efforts needed to provide income protection to low- and middle-income households against the economic shock. More generally, our work contributes to the limited literature studying the role of taxbenefit systems in protecting incomes during economic recessions in Latin America (Daude et al. 2011; Martorano 2018; Vegh et al. 2019). In particular, the study of taxes and benefits as automatic stabilizers has seldom been analysed for Latin America making use of microsimulation techniques. To the best of our knowledge, only Espino and González Rozada (2012) have made use of microsimulation techniques to estimate the size of automatic stabilizers in selected Latin American countries. Their study focuses on Argentina, Brazil, Mexico, Nicaragua, and Peru with data from 2005 and 2006. Our analysis therefore complements this study, looking at the role of automatic stabilizers in Ecuador in the context of the COVID-19 crisis.

The remainder of the paper is structured as follows. Section 2 provides a brief overview of the growing literature analysing the economic and distributional effects of COVID-19. Section 3 discusses the main social protection instruments in Ecuador and the emergency tax-benefit policies implemented by the government to mitigate the impact of COVID-19. Section 4 presents

\footnotetext{
2 The 2019 national poverty lines of US $\$ 85.03$ per month for poverty and US $\$ 47.92$ per month for extreme poverty are used in the analysis.
} 
the methods and data. Section 5 is dedicated to the analysis of the empirical results. Finally, Section 6 concludes.

\section{Related research}

Recent forecasts by ECLAC depict a grim economic scenario in the region as a result of the COVID-19 pandemic, with GDP growth projected at -9.1 per cent in 2020 and the regional unemployment rate estimated at 13.5 per cent at the end of the year (ECLAC 2020b). The projected drop in GDP growth in Ecuador is close to the regional average, representing a 9 per cent contraction. Moreover, as this crisis has both supply and demand components, the intensity of the effects by sector of economic activity may be heterogenous (ECLAC 2020a), with sectors whose activities involve crowding and physical closeness, such as tourism, wholesale and retail trade, hotels and restaurants, and some manufacturing activities, among the most affected.

In terms of the labour market, most studies have concentrated on assessing the effects on employment in the immediate aftermath of the COVID-19 outbreak due to the lockdown measures imposed by national governments. In the USA, employment rates fell by about 12 percentage points during the first four months of 2020, where 60 per cent of the decline is explained by the introduction of social distancing measures (Gupta et al. 2020). The literature has also highlighted between- and within-country differences in the impact of COVID-19 on the labour market. Adams-Prassl et al. (2020) show that employees in Germany are less affected by the crisis due to their well-established short-time work scheme. Other studies have corroborated the smaller employment impact in industries and occupations where remote working can be adopted more easily (Béland et al. 2020; Bonavida and Gasparini 2020). The severity of the crisis in Latin America has been highlighted by Bottan et al. (2020), who use online surveys of 17 countries in the region to show that around 45 per cent of respondents have a member of the household who lost their job during April 2020. In addition to an increase in unemployment, Latin American countries might also experience reductions in formal employment. Altamirano et al. (2020) estimate a drop in formal employment of between 4.4 and 14.8 per cent on average by the end of 2020 in Latin America, depending on the severity of the crisis. Their study further highlights that the impact on formal employment will vary across industries, with the wholesale and retail sector and that of hotels and restaurants being the most affected.

A growing number of studies have analysed the distributional impacts of COVID-19, with worrisome forecasts for the evolution of poverty and inequality. Sumner et al. (2020) estimate a substantial increase in poverty, with up to 400 million new people entering poverty worldwide based on the US $\$ 1.90$ per day poverty line. For Latin America, ECLAC (2020b) projects an increase in poverty by 7.1 percentage points on average and extreme poverty by 4.5 percentage points by the end of 2020. The forecasts for Ecuador are close to the regional average, with an increase in (extreme) poverty by 7.0 (5.1) percentage points. The Gini coefficient is expected to increase by between 1 and 8 percentage points, with Ecuador expected to experience one of the largest increases in the region.

However, the above-mentioned studies do not take into account the potential effect of tax-benefit policies and emergency measures implemented by national governments to mitigate the effect of the crisis. Recent studies making use of tax-benefit microsimulation models have accounted for the impact that COVID-related emergency measures would have in reducing poverty and inequality in developed countries. Figari and Fiorio (2020) assess the welfare compensation provided by the tax-benefit system to those who lost earnings as a result of the lockdown in March 2020 in Italy. Beirne et al. (2020) assess the budgetary and distributional effects of COVID-related 
policies in Ireland under hypothetical unemployment shock scenarios. Brewer and Tasseva (2020) study the role of tax-benefit automatic stabilizers and COVID-related policies in mitigating the impact of the crisis on the employment situation in April 2020 in the UK. Bronka et al. (2020) forecast the evolution of the employment shock across UK industries and study the impact on UK household incomes for the whole of 2020. All these studies highlight the important role played by COVID-related emergency measures to mitigate the economic shock from the pandemic.

Evidence on the distributional effect of automatic stabilizers and COVID-related measures in developing countries is scarce. Unlike in developed economies, we might expect tax-benefit policies to play a more modest role in providing protection against employment shocks for various reasons. First, social protection remains limited in the developing world due to limited fiscal capacity and budgetary pressure. Second, informal employment is highly prevalent in developing countries. As a result, a large proportion of the work force does not contribute to social security and is not covered by contributory benefits, such as unemployment insurance (where it exists). Third, cash transfer programmes are usually based on proxy means-testing and therefore might fail to act as automatic stabilizers following employment and income shocks. Lustig et al. (2020) simulate potential income losses due to lockdown measures based on household survey data from Argentina, Brazil, Colombia, and Mexico. Their study identifies individuals whose income is at risk due to their sector of work and then simulates income losses at the household level. Their results show a larger increase in poverty and inequality compared to studies that assume a uniform decrease in earnings and point to an important effect of expanded social assistance programmes in mitigating the impact of lockdown in Brazil and Argentina only.

Our analysis is in line with the study by Lustig et al. (2020). However, we focus on the impact over the period when the economy was the most affected rather than looking at the annualized impact of the pandemic. Moreover, rather than simulating potential income losses based on industries at risk, we use information from household survey data collected during the lockdown period in May/June 2020 in Ecuador, and we adjust the pre-COVID data to reflect the actual changes in employment and earnings as a result of the pandemic. Finally, we exploit the use of tax-benefit microsimulation and decomposition techniques to quantify the distributional effects of: (i) earnings losses due to COVID-19, (ii) pre-crisis tax-benefit policies (i.e. automatic stabilizers), and (iii) COVID-related tax-benefit measures implemented by the government.

\section{$3 \quad$ Social protection in Ecuador and policy measures in response to COVID-19}

This section first describes the level of social protection spending and government revenues in Ecuador compared to other countries. It then briefly reviews the main social protection transfers in Ecuador, as well as the policies that the government has implemented to mitigate the COVID19 crisis.

Relative to developed economies, social protection in low- and middle-income countries remains modest due to limited fiscal capacity. Government spending on social protection represents, on average, 4.1 per cent of GDP in Latin America compared to 12 per cent of GDP in OECD countries (ECLAC 2019; OECD 2019). ${ }^{3}$ Spending on social protection in Ecuador is below the regional average, representing 1.44 per cent of GDP. Contributory social security benefits have little coverage in the country and consist mainly of contributory old-age pensions. Coverage of

\footnotetext{
${ }^{3}$ For comparability, OECD estimates include only spending in pensions and income support to the working age population.
} 
non-contributory programmes has decreased over the last years due to budgetary pressure. In terms of taxes, the average tax-to-GDP ratio in Latin America and the Caribbean (LAC) is 23.1 per cent compared to 34.3 per cent in the OECD (OECD et al. 2020). ${ }^{4}$ LAC countries are also characterized by a different tax composition relative to developed economies. Indirect taxes on goods and services remain important due to their ease of collection. Personal income tax and SICs represent 9.6 per cent and 17.1 per cent respectively of total tax revenue, on average, in the LAC region compared to 23.9 per cent and 26 per cent respectively in the OECD. Tax revenue in Ecuador is below the regional average, with a tax-to-GDP ratio of 20.6 per cent. The contribution of personal income tax is below the regional average, representing around 6 per cent of total tax revenue, whereas the contribution of SICs accounts for 24.5 per cent of total tax revenue.

Individuals and their families can access three main social transfers in Ecuador: the existing Human Development Transfer and the Unemployment Insurance schemes, and the new Family Protection Grant which the government introduced in response to the pandemic. The Human Development Transfer (Bono de Desarrollo Humano) is the main non-contributory social protection scheme in Ecuador and aims to improve human capital and avoid the persistence of poverty by means of monetary transfers to poor families. It is designed as a proxy means-tested benefit, which targets three population subgroups: (i) families with children younger than 18 years old, (ii) elderly adults above 65 years old who are not entitled to any pensions, and (iii) individuals with disabilities. ${ }^{5}$ The proxy means-test is based on a composite index comprising household characteristics and housing conditions. Families and individuals below a specific threshold of the index are eligible for the benefit, and certain conditionalities apply to families with children. ${ }^{6}$ It is worth noting that household income is not relevant for the proxy means-test and, so, benefit entitlements are not adjusted to cushion income losses per se. Moreover, benefit eligibility is assessed over long periods of time (more than two years) when new official data are collected to recalculate the composite index. Thus, although providing an important income protection for existing recipients, by design, this benefit does not act as an income stabilizer during the initial shock of the pandemic. As of 2019, the Human Development Transfer counted around 1 million beneficiaries.

The Unemployment Insurance scheme (Seguro de desempleo), introduced back in March 2016, pays out a benefit to unemployed individuals who were previously affiliated to the general social security regime and paid SICs. The benefit amount consists of a fixed payment from a common pool of funds, and a variable top-up payment with funds from an individual account. The scheme consists of five monthly payments, starting after the third month of unemployment. But in response to the pandemic, during the months of April to July 2020, the government reduced the waiting period to ten days. The fixed payment equals 70 per cent of the national minimum wage (US\$400 in 2020). The variable payment tops up the fixed amount up to a maximum benefit amount of 70 per cent of average earnings in the last 12 months of employment. After the first month, the overall payment is reduced by 5 percentage points every month until entitlement stops. In December 2019, the number of Unemployment Insurance recipients amounted to 22,900.

\footnotetext{
${ }^{4}$ Data for 2018 are used for LAC and 2017 data for the OECD average as the 2018 data are not available.

${ }^{5}$ Here, we consider all the sub-programmes of the original Human Development Transfer under the same umbrella: Human Development Transfer for families with children, non-contributory pension assistance, and non-contributory disability benefits.

${ }^{6}$ Two types of conditionality apply for mothers with children receiving the Human Development Transfer. First, it is required that children aged 6-18 years old in the household enrol in school and attend at least 90 per cent of school days in a month. Second, it is required that children below 6 years old in the household attend health centres at least twice per year for medical check-ups.
} 
To mitigate the impact of the COVID-19 crisis, the Ecuadorian government introduced the Family Protection Grant (Bono de Protección Familiar) in March 2020. The transfer targets two population groups under a two-stage process and represents a cash transfer of US $\$ 120$ paid in two monthly instalments (i.e. US $\$ 60$ each month). ${ }^{7}$ In the first stage, the poorest 400,000 households in the country are targeted. In order to be eligible, (i) the person must: be affiliated to the rural workers or unpaid work social security regimes, (ii) the person must: earn less than US $\$ 400$ per month (equivalent to the legal minimum wage), and (iii) no members of the household should be receiving contributory or non-contributory benefits or pensions (Presidencia de la República 2020a). In the second stage, it targets 500,000 additional households, excluding stage one beneficiaries. To be eligible, (i) the head of the household must earn less than US $\$ 501.60$ per month (equivalent to the official cost of a survivor basket of food and services) and (ii) no member of the household should be receiving contributory or non-contributory benefits or pensions (Presidencia de la República $2020 \mathrm{~b})$. The transfer, therefore, aims to cover the poorest 21 per cent of households in the country which fulfil the eligibility conditions.

Some other policies have been implemented as a result of the COVID-19 pandemic, but, because of their design, it is not possible to take them into account within our simulation analysis in a consistent manner. First, the government has introduced the possibility of reducing the working hours (up to 25 per cent of the working day) and, correspondingly, wages of civil servants (Presidencia de la República 2020c). However, this policy does not apply universally to all public institutions and has some degree of discretion. A similar policy has been introduced affecting workers in the private sector (Asamblea Nacional 2020). In this case, the implementation of these policies depends on the so-called 'agreement between the parties', meaning there is no general rule. Second, sub-national governments have delivered food baskets on demand and without allocation rules. The content and quantity of products vary from city to city. Finally, there are lines of credit to support small businesses from international aid and from international organizations such as the World Bank, the Inter-American Development Bank, or International Monetary Fundprepared emergency funds.

\section{$4 \quad$ Methodology}

Our study makes use of ECUAMOD, the tax-benefit microsimulation model for Ecuador, based on representative household microdata, to assess the distributional effects of COVID-19 in Ecuador. This section starts by presenting the data and microsimulation model used in the analysis. Then, it discusses the data adjustment made to capture the labour market situation during the first phase of the COVID-19 pandemic that we analyse. Finally, we describe the method used to assess the distributional impact of the COVID-19 crisis in May/June 2020.

\subsection{Data}

Our analysis is based on representative household survey data from the National Survey of Employment, Unemployment and Underemployment of Urban and Rural Households (ENEMDU). ENEMDU is conducted on a quarterly basis and represents the main data source for tracking the evolution of poverty and inequality in the country. The latest data available for distributional analysis are for December 2019 (INEC 2019), which we use in our study to capture the labour market situation prior to the COVID-19 pandemic. The data used in our analysis

\footnotetext{
${ }^{7}$ US $\$ 60$ is equivalent to 70.6 per cent of the national poverty line in 2019.
} 
contain information for 17,001 households and 59,183 individuals. Hereafter, we refer to this data as ENEMDU 2019.

ENEMDU 2019 contains information on labour and non-labour income, public pensions, cash transfers, private transfers, as well as personal and household characteristics. It also contains information on affiliation to social security, which we use to define formal employment. ${ }^{8}$ Informal employment in our analysis is therefore defined as non-affiliation to social security. An important limitation of ENEMDU for our simulations is the lack of information on expenditures. Expenditure data is needed for the simulation of personal income tax, as deductions for certain personal expenditures apply to the calculation of taxable income. For the purpose of personal income tax simulations, we imputed expenditure in food, clothing, education, health, and housing to ENEMDU based on information from the National Survey of Income and Expenditures of Urban and Rural Households (ENIGHUR 2011-12) (ANDA 2012). ${ }^{9}$

The COVID-19 outbreak affected survey data collection for ENEMDU with suspension of inperson household surveys. In-person data collection for ENEMDU during the first quarter of 2020 was suspended on 16 March 2020. As a result, only 48 per cent of households were covered by the survey in the first quarter of 2020 and because of this limitation, the data were not released to the public (INEC 2020a). In order to provide information about the labour market situation during the pandemic, the National Institute for Statistics and Censuses (INEC) conducted phone surveys to collect data from the second quarter of 2020 (INEC 2020b), with advisory technical support from international organizations such as the World Bank, ECLAC, and the International Labour Organization. Hereafter, we refer to this data as ENEMDU 2020. The focus of the survey was to characterize the recent labour market developments under the COVID-19 pandemic. For this reason, the number of variables collected was restricted and household identifiers were not released as part of the public data. ${ }^{10}$ Therefore, ENEMDU 2020 cannot be used directly as input data in our simulations. However, it can be used to generate aggregate information on employment and earnings by industry to adjust ENEMDU 2019 and derive input data capturing the Ecuadorian labour market situation during the second quarter of 2020. ENEMDU 2020 also contains information on the number of beneficiaries of the COVID-related Family Protection Grant and the unemployment insurance benefit (Seguro de desempleo), which we use to calibrate our simulations of these benefits in the analysis.

\subsection{Tax-benefit simulations}

We use ECUAMOD, the tax-benefit microsimulation model for Ecuador, which has been developed as part of UNU-WIDER's project on 'SOUTHMOD—simulating tax and benefit policies for development', in which tax-benefit microsimulation models have been built for

\footnotetext{
${ }^{8}$ In general, ENEMDU captures well information on affiliation to social security as the data are cross validated with information from the Ecuadorian Institute of Social Security (Instituto Ecuatoriano de Seguridad Social, IESS)

${ }^{9}$ Unlike ENEMDU, ENIGHUR contains information on both income and expenditures. However, ENIGHUR data are not collected on a regular basis and the latest data available are for years 2011-12. Expenditure amounts in ENIGHUR 2011-12 are updated to 2019 values using the Consumer Price Index when imputed to ENEMDU 2019. A two-step procedure is used for the imputation. First, we estimate a probit model to determine which households are more likely to have each type of expenditure. Then, conditional on having positive expenditures, we estimate a linear regression for the amount of expenditures. Household disposable income, characteristics of the household, and household head are used as regressors.

10 The ENEMDU 2020 phone survey contains information for 37,406 individuals, one third were interviewed in May and two-thirds in June. In order to avoid a decrease in the response rates of ENEMDU, the size of the questionnaire was reduced for the phone interviews. The questionnaire designed for ENEMDU 2020 contains 81 questions compared to 227 questions included in the traditional ENEMDU (INEC 2020).
} 
selected developing countries (Decoster et al. 2019). ECUAMOD combines detailed countryspecific coded policy rules with household survey microdata to simulate direct and indirect taxes, SICs, and cash transfers for the household population of Ecuador. The model has been implemented on the EUROMOD software to ensure harmonization for cross-country comparative analysis on the redistributive effect of tax-benefit policies (see Sutherland and Figari 2013). ECUAMOD is a static model in the sense that tax-benefit simulations abstract from behavioural reactions of individuals and no adjustments are made for changes in the population composition over time. Simulation results for ECUAMOD have been validated against official statistics (see Jara and Montesdeoca 2020) and the model has been used in recent empirical studies by Bargain et al. (2017), Jara and Varela (2019), and Jouste and Rattenhuber (2019).

ECUAMOD is used to simulate the main tax and benefit components of household disposable income in Ecuador. More precisely, we use ECUAMOD to simulate: (i) SICs and (ii) personal income tax for workers reporting affiliation with social security; (iii) the Human Development Transfer, which represents the main social protection programme in the country; (iv) unemployment insurance (Seguro de desempleo); and (v) the COVID-related Family Protection Grant. Non-simulated benefits, such as pensions, are taken directly from the data. Disposable income is defined as the sum of market income plus social cash transfers (including pensions) minus income tax and SICs. ${ }^{11}$ ECUAMOD is used to simulate the distribution of household disposable income before and during the COVID-19 pandemic to assess the impact of the outbreak and lockdown measures. The pre-COVID scenario corresponds to the distribution of household disposable income in December 2019 based on ENEMDU 2019. The COVID scenario corresponds to the situation in May/June 2020 based on adjusted microdata from ENEMDU 2019 reflecting the labour market and earnings situation provided by ENEMDU 2020. The distribution of household disposable income in the COVID scenario is obtained by running ECUAMOD with 2020 taxbenefit policies, including the Family Protection Grant - the main emergency policy introduced by the government-on the adjusted ENEMDU 2019. The adjustment made to ENEMDU 2019 to reflect the labour market and earnings situation from ENEMDU 2020 is discussed in detail in the next section.

\subsection{Simulating changes in employment and earnings due to COVID-19}

As previously mentioned, our COVID scenario is derived using the information from ENEMDU 2020. More precisely, we adjust the labour market and earnings information in ENEMDU 2019 to reflect the situation in May/June 2020 captured in ENEMDU 2020. We start this section by comparing the changes in the labour market and earnings between December 2019 and May/June 2020. Then, we discuss the approach taken to adjust ENEMDU 2019 to reflect the situation of the economy in May/June 2020.

Figure 1 presents the changes in the labour market for the working-age population in Ecuador (above 15 years old) between December 2019 and May/June 2020. The figure shows the number of people in work, unemployment, and inactivity (excluding full-time students, pensioners, and individuals with a disability). For those in work, we distinguish between those in formal and informal employment and those with positive and zero earnings.

\footnotetext{
${ }^{11}$ Market income is defined as the sum of employment and self-employment income, bonuses, in-kind income, ownconsumption from self-employment activities, capital and property income, inter-household payments, and private transfers, minus alimony payments. Imputed rent is not included as part of market income.
} 
Figure 1: Changes in the labour market between December 2019 and May/June 2020 (in thousands of workers)

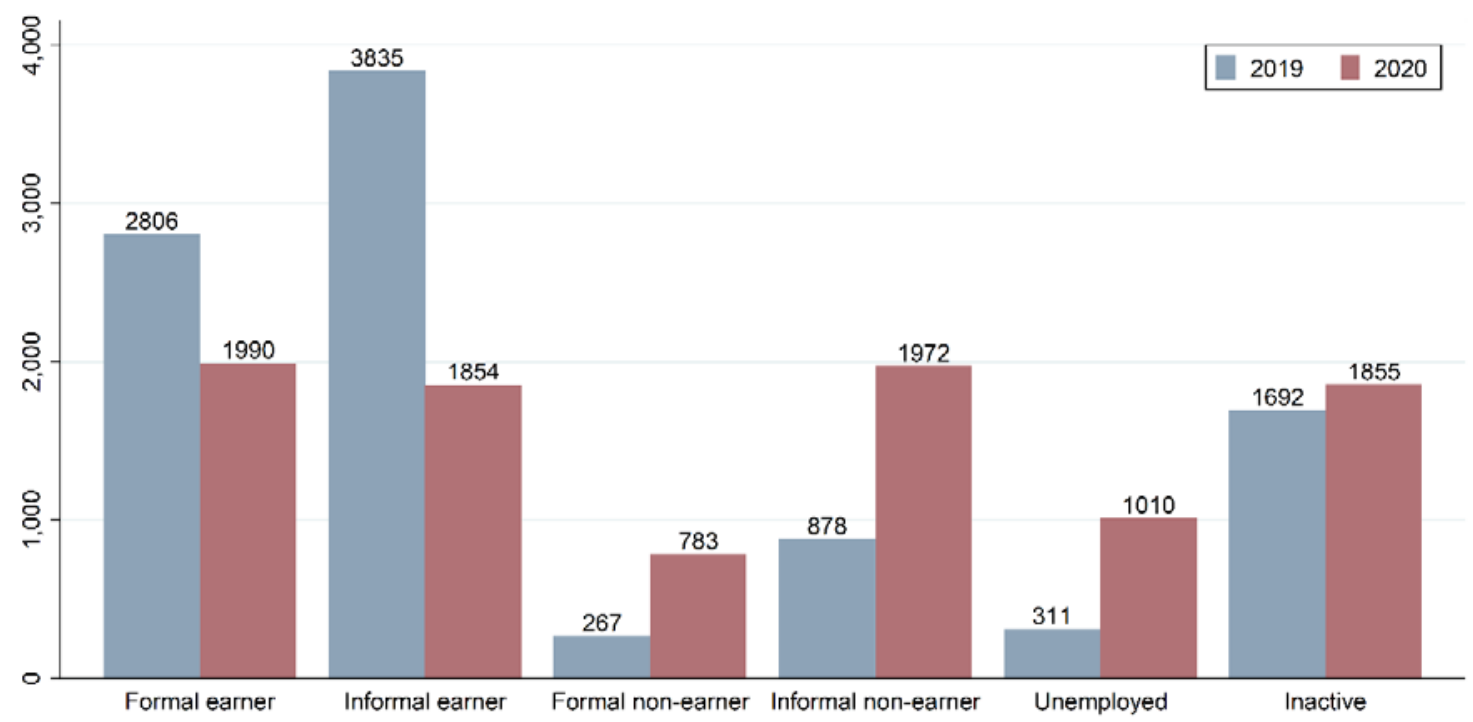

Source: authors' elaboration based on ENEMDU 2019 (INEC 2019) and ENEMDU 2020 (INEC 2020b).

The results show the striking effect of the COVID-19 pandemic in the Ecuadorian labour market. The number of people in work has decreased by 15 per cent (from 7.8 to 6.5 million). The number of people in unemployment has more than tripled from 311,134 to over 1 million individuals. Inactivity has also increased, by around 10 per cent. In addition to the large increase in unemployment, the COVID-19 pandemic and lockdown measures have resulted in earning losses for a large fraction of people in work. The number of workers (formal and informal employment) reporting positive earnings has dropped by 42 per cent. The fall has been particularly large for informal earners, representing a 52 per cent decrease (from 3.8 to 1.9 million workers) whereas the number of formal earners has decreased by 29 per cent (from 2.8 to 1.99 million). As a counterpart, the number of workers reporting no earnings has substantially increased. ${ }^{12}$ According to ENEMDU 2020, the number of formal workers reporting zero earnings has almost tripled (from 266,555 to 782,822 ) compared to ENEMDU 2019. Over the same period, the number of informal workers with no earnings has more than doubled from 877,664 to 1,971,712.

The labour market effect of the pandemic by sector of activity is presented in Figure 2, which shows the total number of earners (top of the bars) per industry in December 2019 and in May/June 2020, distinguishing between formal (blue bars) and informal earners (red bars).

\footnotetext{
${ }^{12}$ In 2019, this category accounts mainly for unpaid work, whereas in 2020 this category also captures self-employed workers with zero earnings and furloughed workers, where, unlike in developed countries, no furlough allowance schemes have been implemented in Ecuador.
} 
Figure 2: Number of formal and informal earners in December 2019 and May/June 2020 (in thousands of workers)

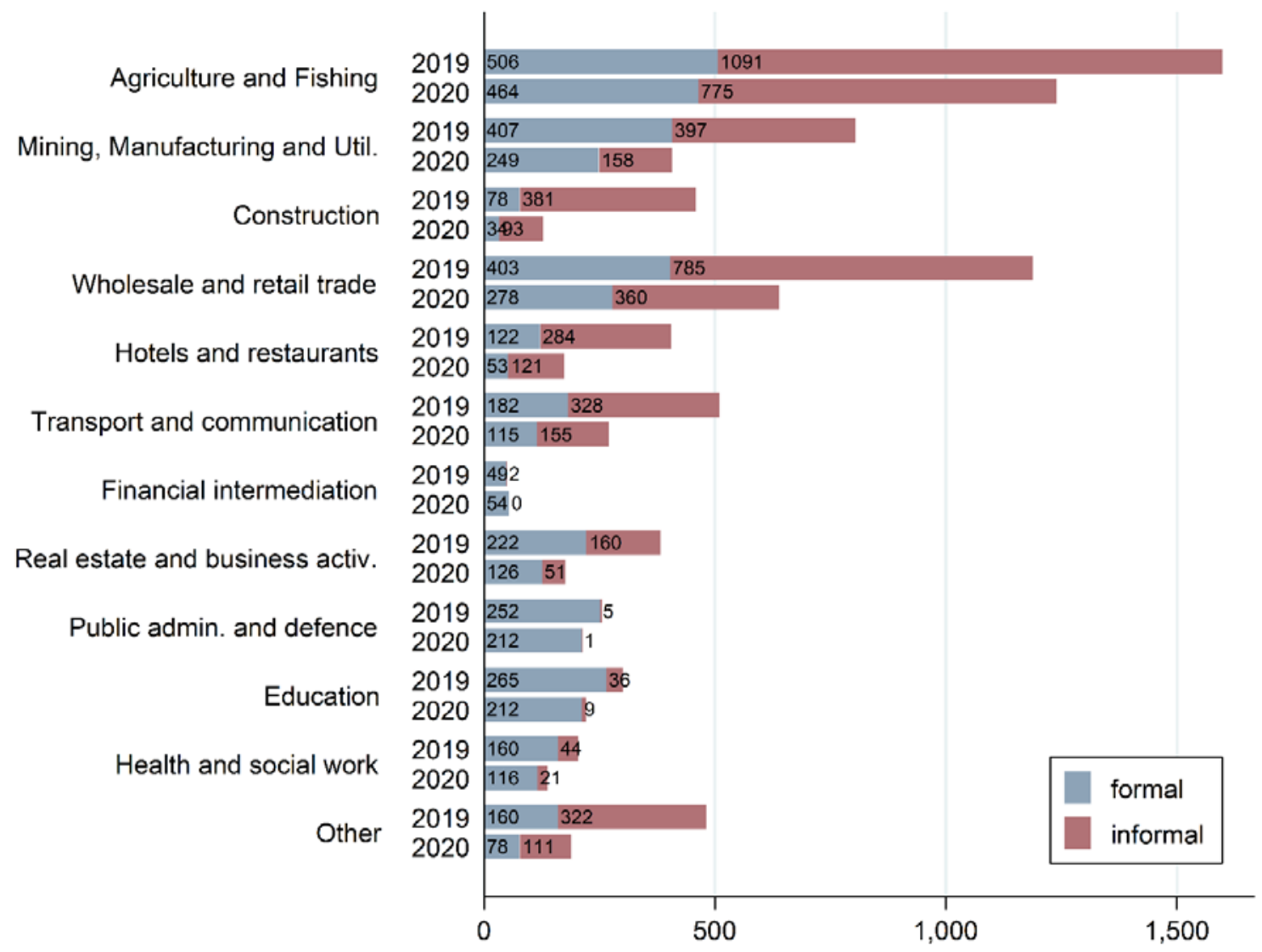

Source: authors' elaboration based on ENEMDU 2019 (INEC 2019) and ENEMDU 2020 (INEC 2020b).

The largest decrease in the number of earners (formal and informal) is observed in the wholesale and retail trade sector, with a drop of 549,000 earners. The mining, manufacturing, and utilities sector follows, with a reduction of 397,000 earners. Other large changes are observed in agriculture and fishing and in the construction sector. The results for agriculture and fishing highlight the importance of the availability of data that capture the changes in the labour market under the COVID-19 pandemic. Studies based on indices of at-risk industries usually assume that 'essential' sectors such as agriculture are not affected by the COVID-19 pandemic and lockdown measures (e.g. Lustig et al. 2020), whereas data for Ecuador show a drop in the number of earners in the agriculture and fishing sector mainly driven by a decrease in the number of informal earners in this sector. As stressed by the Food and Agriculture Organization (FAO 2020), informal workers in the agriculture sector are affected by disruptions in the agri-food supply chains and markets due to lockdown measures, facing decreased demand for agricultural products. In all other sectors, except in public administration and defence, the reduction in the number of earners is also widely driven by the fall in the number of informal earners. In the wholesale and retail trade sector, for instance, the reduction in the number of informal earners accounts for 77 per cent of the reduction of total earners. The only sector that has experienced an increase in the number of earners is financial intermediation, due to an increase in the number of formal earners, whereas the number of informal earners in this sector has dropped.

At the intensive margin, i.e. for those reporting positive earnings, we can also observe an impact from the crisis. Table 1 reports mean earnings by industries, distinguishing between formal and informal earners and employees versus self-employed workers. In order to avoid categories with a small number of observations, we have regrouped financial intermediation, real estate, and 
business activities into a single category and public administration and defence, education, health and, social work into another category.

Table 1: Mean monthly earnings by industry in December 2019 and May/June 2020 (in USD)

\begin{tabular}{|c|c|c|c|c|c|c|c|c|}
\hline & \multicolumn{4}{|c|}{ ENEMDU 2019} & \multicolumn{4}{|c|}{ ENEMDU 2020} \\
\hline & \multicolumn{2}{|c|}{ Formal } & \multicolumn{2}{|c|}{ Informal } & \multicolumn{2}{|c|}{ Formal } & \multicolumn{2}{|c|}{ Informal } \\
\hline & Employees & $\begin{array}{l}\text { Self- } \\
\text { employed }\end{array}$ & Employees & $\begin{array}{c}\text { Self- } \\
\text { employed }\end{array}$ & Employees & $\begin{array}{c}\text { Self- } \\
\text { employed }\end{array}$ & Employees & $\begin{array}{c}\text { Self- } \\
\text { employed }\end{array}$ \\
\hline $\begin{array}{l}\text { Agriculture and } \\
\text { fishing }\end{array}$ & 411.2 & 215.5 & 226.8 & 135.7 & 298.5 & 70.9 & 164.8 & 67.3 \\
\hline $\begin{array}{l}\text { Mining, manufact. } \\
\text { and utilities }\end{array}$ & 702.4 & 550.0 & 316.6 & 255.6 & 631.2 & 284.5 & 214.2 & 135.1 \\
\hline Construction & 567.3 & 870.1 & 361.5 & 407.6 & 483.7 & 515.1 & 175.5 & 153.0 \\
\hline $\begin{array}{l}\text { Wholesale and } \\
\text { retail trade }\end{array}$ & 607.0 & 568.6 & 315.4 & 292.7 & 529.4 & 289.2 & 239.9 & 137.3 \\
\hline $\begin{array}{l}\text { Hotels and } \\
\text { restaurants }\end{array}$ & 459.6 & 798.4 & 254.2 & 264.8 & 380.0 & 130.4 & 170.7 & 115.9 \\
\hline $\begin{array}{l}\text { Transport and } \\
\text { communication }\end{array}$ & 791.1 & 569.4 & 414.1 & 372.9 & 725.0 & 221.6 & 312.4 & 156.2 \\
\hline $\begin{array}{l}\text { Financial } \\
\text { intermediation, real } \\
\text { estate and business } \\
\text { activities }\end{array}$ & 646.5 & 741.3 & 302.8 & 396.8 & 605.3 & 354.4 & 352.6 & 258.6 \\
\hline $\begin{array}{l}\text { Public } \\
\text { administration and } \\
\text { defence; education; } \\
\text { health and social } \\
\text { work }\end{array}$ & 925.0 & 749.1 & 358.6 & 293.0 & 916.5 & 206.5 & 350.1 & 219.0 \\
\hline Other & 425.7 & 430.4 & 248.2 & 201.7 & 400.2 & 291.9 & 220.7 & 95.1 \\
\hline All & 691.5 & 466.3 & 288.4 & 260.4 & 655.7 & 158.0 & 196.0 & 114.9 \\
\hline
\end{tabular}

Source: authors' elaboration based on ENEMDU 2019 (INEC 2019) and ENEMDU 2020 (INEC 2020b).

On average, for the whole population of earners, mean monthly earnings decreased by 18 per cent from US $\$ 460.5$ in December 2019 to US\$376.3 in May/June 2020. The decrease in earnings has been particularly important for formal self-employed workers, amounting to a 59 per cent reduction (from US\$508.6 to US\$208.0) in mean monthly earnings, compared to an 18 per cent reduction (from US\$731.6 to US\$672.5) for formal employees. Table 1 further shows the heterogenous effect of the pandemic on earnings across industries. The largest drop in mean earnings is observed for formal self-employed workers in hotels and restaurants (84 per cent decrease), followed by formal self-employed workers in the category of public administration and defence, education, health, and social work (72 per cent decrease), and informal self-employed workers in the construction sector (62 per cent decrease). In the category of financial intermediation, real estate, and business activities, mean earnings of informal employees have increased. However, this corresponds to small samples of informal workers.

Based on the information of the number of earners (Figure 2) and mean earnings per industry (Table 1), we adjust the data in ENEMDU 2019 to create microdata reflecting the labour market situation and earnings distribution captured by ENEMDU 2020. More precisely, we modify the labour market status and earnings of individuals in the 2019 ENEMDU to match the number of formal and informal earners per industry and mean earnings reflected in the 2020 ENEMDU. For this purpose, we estimate a probit model of the probability of being unemployed on a sample of individuals in work or unemployment using the 2020 ENEMDU. The dependent variable is one if the person is unemployed, zero otherwise. As regressors, we include sex, age, education dummies, a dummy for being married, a dummy for living in the rural area, and interactions 
between a female dummy and all other variables. Results from the probit estimation are presented in Table A1 in the Appendix.

The estimated coefficients are then used to predict the probability of being unemployed in ENEMDU 2019. The predictions are based on each person's characteristics, multiplied by the coefficients plus a random component that accounts for unobserved factors that may tip people into unemployment. The addition of the random term means that we do not completely exclude lowest-risk groups from unemployment ( $\mathrm{Li}$ and Donoghue 2014). Based on these predicted probabilities, we move individuals from being formal and informal earners to having zero earnings in order to match the number of formal and informal earners in Figure 2. For this, we first rank formal and informal earners according to their probability of being unemployed and select by industry those with the lowest probability of being unemployed to remain in the status of formal and informal earners. Then, we set to zero all earnings of those individuals who are not selected to remain as earners. Table A2 in the Appendix shows the descriptive statistics from the original and adjusted microdata. Finally, for those individuals that remain as formal and informal earners, we adjust their earnings so that the mean earnings per industry and employment status (employee versus self-employed) in the adjusted microdata reflects the information of mean earnings per industry and employment status in the 2020 ENEMDU (Table 1). ${ }^{13}$ Note that in reality some workers within these categories might not have experienced changes to their earnings; however, the data do not allow us to identify these workers and a further disaggregation by individual characteristics (e.g., gender, education) reduces the number of observations in each category.

\subsection{Decomposing changes in the distribution of household disposable income}

In addition to comparing the distribution of household disposable income before and after COVID-19, we follow the decomposition approach proposed by Bargain and Callan (2010), extended by Paulus and Tasseva (2020), and recently applied to the context of the COVID-19 crisis in the UK by Brewer and Tasseva (2020). The method consists of simulating a series of counterfactual scenarios with the aim of isolating the distributional effects of: (i) earnings losses due to COVID-19, (ii) pre-crisis tax-benefit policies (i.e. automatic stabilizers), and (iii) COVIDrelated emergency measures implemented by the government. This section follows closely the description of the decomposition by Brewer and Tasseva (2020).

Let $y$ represent pre-crisis gross market income, $t(y)$ income tax and SICs, and $b(t, y)$ government cash transfers. Then, household disposable income in the pre-crisis baseline scenario is given by:

$$
\mathrm{B}=\mathrm{y}-\mathrm{t}(y)+\mathrm{b}(t, y)
$$

Now, let $y^{\prime}$ represent gross market income under the crisis reflecting a scenario with higher unemployment and lower earnings, $t\left(y^{\prime}\right)$ denote income tax and SICs after the drop in earnings, and $b^{\prime \prime}\left(t, y^{\prime}\right)$ represent government cash transfers after the earnings drop and benefit changes, e.g. newly introduced cash transfers. Then, the household disposable income under the crisis is given by:

$$
\mathrm{D}=\mathrm{y}^{\prime}-\mathrm{t}\left(y^{\prime}\right)+\mathrm{b}^{\prime \prime}\left(t, y^{\prime}\right)
$$

A welfare index, $I$, such as mean income or a measure of inequality or poverty, can be calculated on the basis of the distribution of disposable income under the pre-crisis and crisis scenarios. The

\footnotetext{
13 The adjustment is made for those categories where mean earnings changed by more than 5 per cent between December 2019 and May/June 2020.
} 
total difference $\Delta$ in the welfare indicator $I$ between the pre-crisis and crisis scenarios can be represented by:

$$
\Delta=I\left[\mathrm{y}^{\prime}-\mathrm{t}\left(y^{\prime}\right)+\mathrm{b}^{\prime \prime}\left(t, y^{\prime}\right)\right]-I[\mathrm{y}-\mathrm{t}(y)+\mathrm{b}(t, y)]
$$

The difference in the distribution of disposable income, as summarized by index $I$, can be decomposed into the contribution of the change in the tax-benefit rules ('policy changes effect') and the contribution of 'other effects' not directly linked to policy changes, such as the changes in the underlying gross market income distribution due to the economic shock. ${ }^{14}$ Formally, this can be represented as:

$$
\begin{aligned}
& \Delta=\left\{I\left[\mathrm{y}^{\prime}-\mathrm{t}\left(y^{\prime}\right)+\mathrm{b}^{\prime \prime}\left(t, y^{\prime}\right)\right]-I\left[\mathrm{y}^{\prime}-\mathrm{t}\left(y^{\prime}\right)+\mathrm{b}\left(t, y^{\prime}\right)\right]\right\} \text { (policy } \\
& \text { changes) } \\
& +\left\{I\left[\mathrm{y}^{\prime}-\mathrm{t}\left(y^{\prime}\right)+\mathrm{b}\left(t, y^{\prime}\right)\right]-I[\mathrm{y}-\mathrm{t}(y)+\mathrm{b}(t, y)]\right\} \text { (other effects) }
\end{aligned}
$$

Following Paulus and Tasseva (2020), for additively decomposable measures only, such as mean incomes, we can further decompose the 'other effects' into the effect of earnings changes and the effect of automatic stabilizers. ${ }^{15}$ Equation (4) can be rewritten as:

$$
\begin{aligned}
& \left\{I\left[\mathrm{y}^{\prime}-\mathrm{t}\left(y^{\prime}\right)+\mathrm{b}^{\prime \prime}\left(t, y^{\prime}\right)\right]-I\left[\mathrm{y}^{\prime}-\mathrm{t}\left(y^{\prime}\right)+\mathrm{b}\left(t, y^{\prime}\right)\right]\right\} \quad \text { (policy changes) } \\
& +\left\{I\left[\mathrm{y}^{\prime}\right]-I[\mathrm{y}]\right\} \quad \text { (earnings changes) } \\
& +\left\{I[\mathrm{t}(y)]-I\left[\mathrm{t}\left(y^{\prime}\right)\right]\right\} \quad \text { (taxes and SICs as automatic } \\
& +\left\{I\left[\mathrm{~b}\left(t, y^{\prime}\right)\right]-I[\mathrm{~b}(t, y)]\right\} \quad \text { (benefits as automatic stabilizers) } \\
& +\eta \quad \text { (residual term) }
\end{aligned}
$$

\section{$5 \quad$ Empirical results}

This section presents the results of the distributional effects of COVID-19 and the mitigating effect of tax-benefit policies in May/June 2020, relative to December 2019, in Ecuador. We first discuss the effects on household disposable income, disentangling changes due to earnings losses, automatic stabilizers, and newly implemented emergency policies, and look in detail at the contribution of specific income components. Then, we present the results of the impact of the crisis on income poverty and inequality.

\footnotetext{
${ }^{14}$ Note that, in order to make amounts from two periods comparable when the policies of one period are applied to the population of the other in the counterfactuals, policy parameters and/or market incomes are usually adjusted by a factor capturing the evolution in nominal levels (Bargain and Callan 2010; Paulus and Tasseva 2020). The adjustment factor becomes particularly relevant for distant periods of time. Here, we consider two consecutive years and assume the adjustment factor equals one.

15 For non-additively decomposable measures, such as poverty and inequality indicators, the decomposition in equation (5) also includes a non-zero residual term which can be difficult to interpret (see Paulus and Tasseva 2020 for a discussion).
} 


\subsection{Changes in mean disposable income}

Figure 3 presents the percentage change in mean per capita household disposable income by disposable income decile group and for the whole population. Income deciles are based on per capita household disposable income in the pre-COVID scenario (December 2019 baseline). The changes reflect the difference between the pre-COVID and the COVID scenarios, where the COVID scenario takes into account the role of the health emergency Family Protection Grant introduced by the Ecuadorian government. The change in disposable income is decomposed into the effects of: (i) earnings losses, (ii) automatic stabilizers, and (iii) COVID-related benefits.

Our results show that, on average, household disposable income (white circle) drops sharply by 41 per cent as a result of the COVID-19 pandemic. The fall in household disposable income reflects the losses in earnings (dark grey bar) resulting from the crisis, which account for a 43.8 per cent reduction in disposable income, on average. Our analysis further shows that, on average, the mitigating role of automatic stabilizers (light blue bar) and COVID-related policies (dark blue bar) is extremely modest, with a larger contribution of automatic stabilizers (light blue bar) compared to that of COVID-related policies. Automatic stabilizers contribute to a 2.5 per cent increase in average disposable income for the whole population, whereas COVID-related policies account only for a 0.8 per cent increase.

Figure 3: Change in mean disposable income by income decile

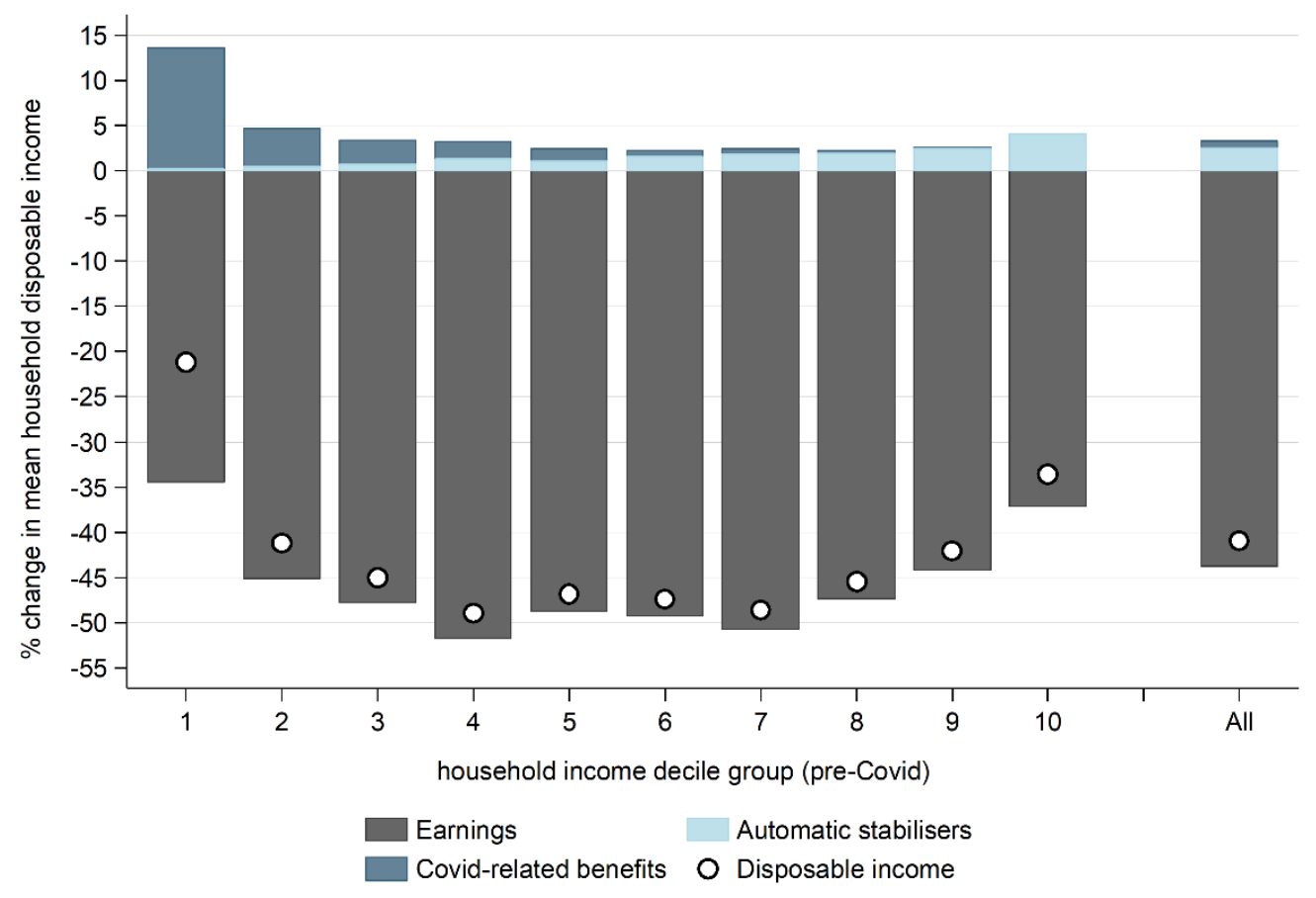

Note: the figure shows the distributional impact of the employment and earnings shocks and the policy response from the Ecuadorian government, i.e. the pre-COVID versus the COVID scenario. Changes in income are based on per capita household disposable income.

Source: authors' elaboration using ECUAMOD v1.5 and ENEMDU 2019 (INEC 2019).

Figure 3 further shows a U-shaped pattern in the change of mean household disposable income across the income distribution. The pattern reflects the changes in earnings across the income distribution, with households in the middle of the income distribution experiencing larger drops in earnings compared to those at the bottom and top. These results are in line with the recent 
study by Lustig et al. (2020) where a similar U-shaped pattern was found in Argentina, Brazil, Colombia, and Chile. The effect of automatic stabilizers and COVID-related policies also varies across the income distribution. The contribution of automatic stabilizers increases with income and they mitigate the effect of the economic shock mostly through their effect in the top decile of the distribution, where they account for 4.1 per cent of household disposable income. COVIDrelated policies play an important role in mitigating the impact of the crisis for households at the bottom of the distribution. For the first income decile group, a 34.5 per cent drop in household disposable income due to earning losses is alleviated by a 13.4 per cent increase as a result of COVID-related policies.

We now turn to the effect of specific income sources and tax-benefit instruments on changes in household disposable income. More precisely, we assess separately the effect of losses in employment versus self-employment earnings, and the contribution of taxes, SICs and benefits to changes in household disposable income, distinguishing between automatic stabilizers and COVID-related policies.

Earnings losses. The contribution of employment and self-employment earnings to changes in household disposable income is depicted in Figure 4, distinguishing between formal and informal workers. On average, for the whole population, losses in formal employment earnings (dark blue bar) account for the largest drop in household disposable income, representing a 14.8 per cent reduction. Losses in informal employment earnings (light grey bar) are slightly smaller, accounting for a 9.3 per cent drop in household disposable income. A reversed pattern is observed for selfemployment earnings, where losses in informal self-employment (dark grey bar) exceed those in formal self-employment (black bar). Formal self-employment losses represent a 6.2 per cent reduction of household disposable income, on average, whereas losses in informal selfemployment earnings account for a 13.5 per cent drop in disposable income.

Figure 4 further highlights how the role of these four income sources varies across the income distribution. Losses in formal employment earnings are larger at the top of the income distribution, representing a 17 per cent reduction in household disposable income in deciles 9 and 10. A different pattern is observed for informal employment earnings, where losses are more prevalent in the middle of the income distribution. Losses in formal self-employment earnings are somewhat uniformly distributed in deciles 1 to 8 , representing a reduction in household disposable income of around 3 per cent, compared with a 6.3 and 9.9 per cent drop in deciles 9 and 10, respectively. Finally, losses in informal self-employment earnings are larger at the bottom of the income distribution, representing a drop in household disposable income of around 21 per cent in the first three deciles, whereas they account for an 8.3 per cent reduction in the top decile of the distribution. 


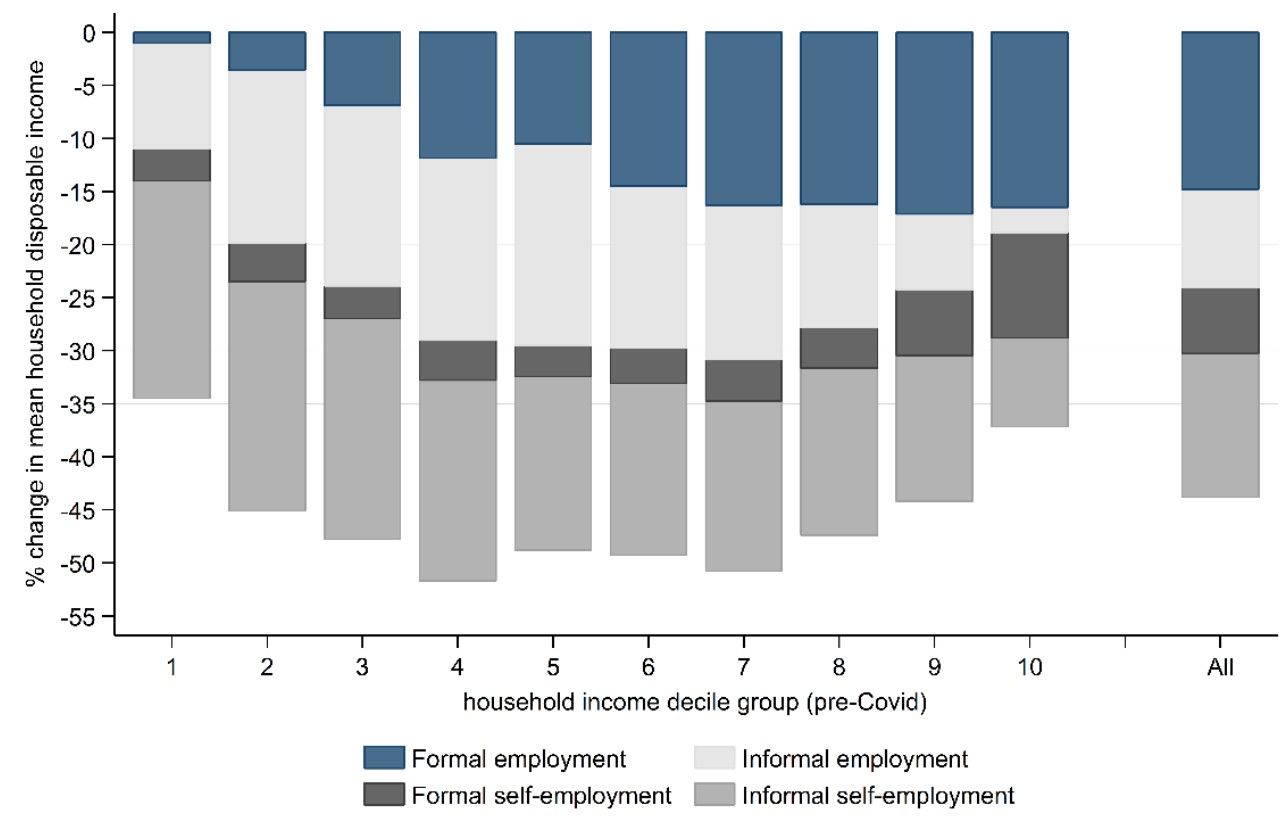

Note: the graph shows the impact of earnings losses on changes in household disposable income. Changes in income are based on per capita household disposable income.

Source: authors' elaboration using ECUAMOD v1.5 and ENEMDU 2019 (INEC 2019).

Automatic stabilizers. The role of specific tax-benefit instruments as automatic stabilizers is presented in Figure 5. More precisely, the figure depicts the change in household disposable income due to automatic changes in personal income tax, SICs, and unemployment insurance under our COVID scenario. On average, SICs provide the largest automatic stabilization, accounting for a 2 per cent increase in household disposable income for the whole population. The contribution of SICs as an automatic stabilizer increases along the income distribution and is largest for the top income decile, where it accounts for a 2.8 per cent increase in household disposable income. The small effect of SICs at the bottom of the distribution can be explained by the prevalence of informal employment, i.e. workers who do not contribute to social security, which is mostly concentrated in lower-income deciles. The effect of income tax also increases with income, it is much smaller than that of SICs and plays a role mostly in the top decile. On average, reductions in personal income tax account for a 0.4 per cent increase in household disposable income, with a larger effect in the top income decile, representing a 1.2 per cent increase in disposable income. In addition to the prevalence of informal employment, the modest contribution of personal income tax is most likely related to the design of this instrument, which is characterized by a high exempted threshold and the presence of deductions for personal expenditures, meaning that personal income tax is highly concentrated at the top of the distribution (Bargain et al. 2017; Jara and Varela 2019). 


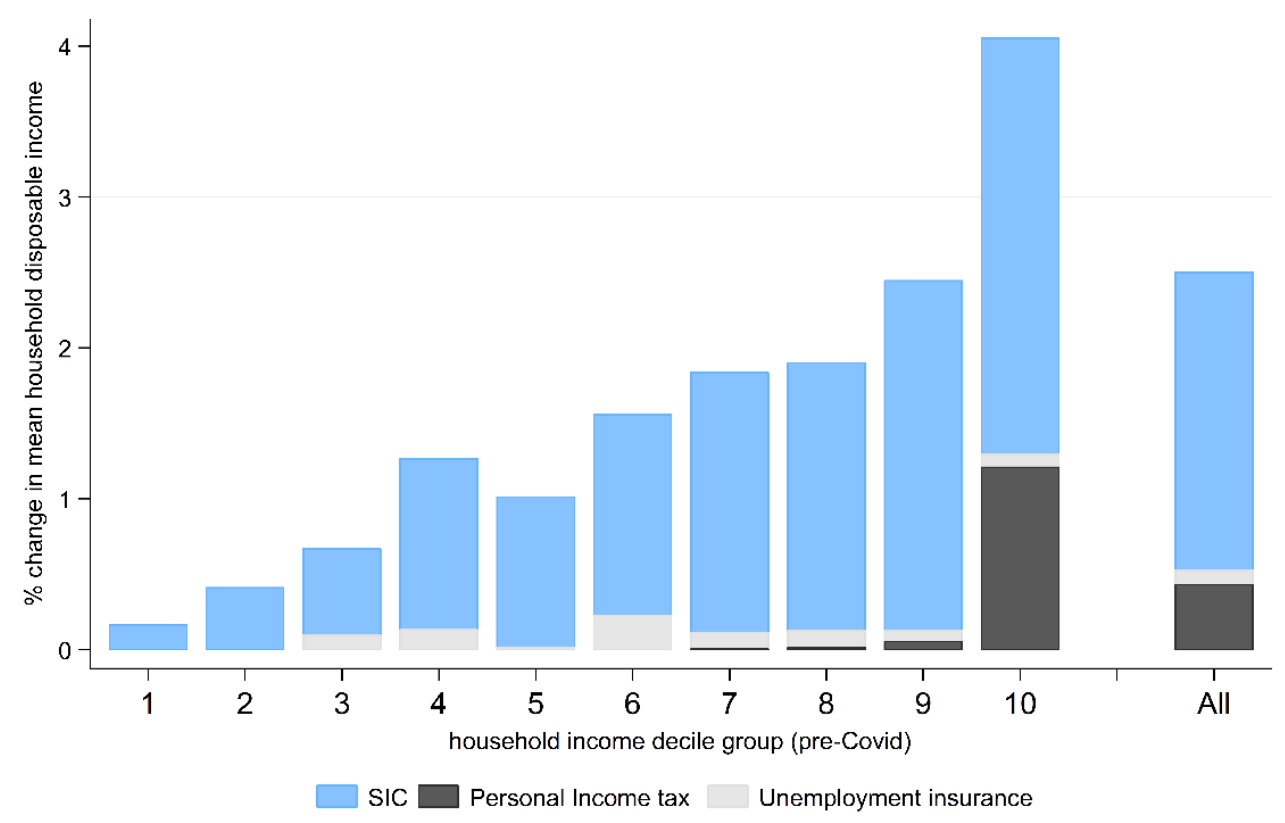

Note: the graph shows impact of automatic stabilizers on changes in household disposable income, i.e. the preCOVID scenario versus the COVID scenario, without emergency measures. Changes in income are based on per capita household disposable income.

Source: authors' elaboration using ECUAMOD v1.5 and ENEMDU 2019 (INEC 2019).

Unemployment Insurance (Seguro de desempleo) also provides limited automatic stabilization and impacts mainly the middle of the distribution. It contributes to an increase in household disposable income of 0.09 per cent, on average. The modest effect of unemployment insurance is explained by the large share of informal workers in Ecuador who are not covered by this benefit, which has been previously documented by Jara (2018). The absence of other benefits as automatic stabilizers protecting incomes at the bottom of the distribution reflects the rigid design of proxy means-tested benefits such as the Human Development Transfer. As previously mentioned, the Human Development Transfer and other proxy means-tested benefits fail to act as automatic stabilizers, as they do not depend directly on earnings but on composite indices capturing the characteristics of household members and housing conditions, and entitlement to such benefits is assessed over long periods of time.

COVID-related policies. The contribution of COVID-related policies to changes in household disposable income is presented in Figure 6 and corresponds to the effect of the Family Protection Grant. As pointed out previously, the COVID-related Family Protection Grant has, on average, a very small effect in mitigating the effect of the crisis in Ecuador. However, it has acted as the main instrument providing income protection to households at the bottom of the income distribution, in the absence of other benefits acting as automatic stabilizers for poor households. By design, the Family Protection Grant has a larger effect for the first decile of the income distribution, accounting for a 13.4 per cent increase in household income on average for this group. The cushioning effect of the Family Protection Grant drops largely for the second decile group, where it contributes to a 4.2 per cent increase in household income, which drops by 41.6 per cent for this group. 


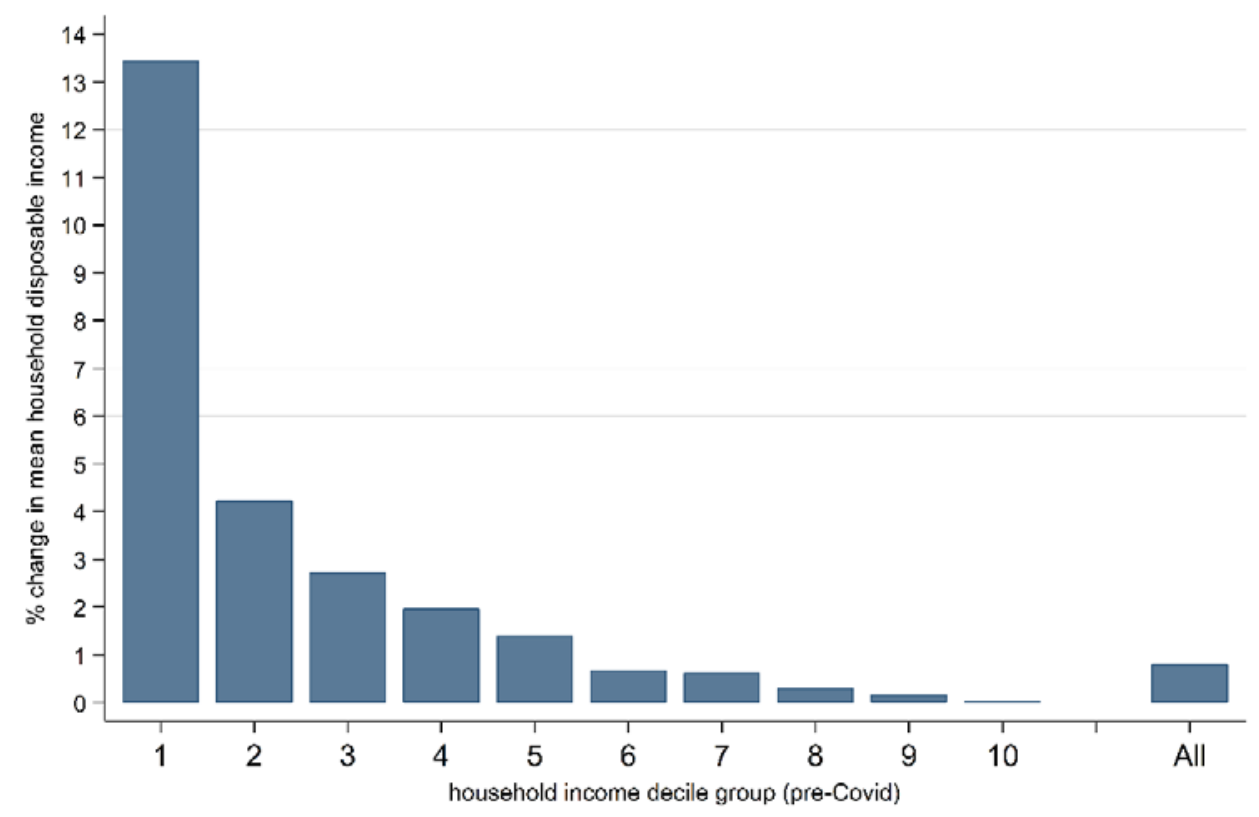

Note: the graph shows the impact of COVID-related policies on changes in household disposable income, i.e. the COVID scenario without versus with emergency tax-benefit measures. Changes in income are based on per capita household disposable income.

Source: authors' elaboration using ECUAMOD v1.5 and ENEMDU 2019 (INEC 2019).

Our results point to two important lessons for the policy debate in the context of the COVID-19 pandemic. First, despite the mitigating role of the Family Protection Grant, this emergency transfer has not managed to offset the adverse effect of the pandemic for low-income households. Second, the crisis has largely affected the middle of the income distribution and no emergency policies have been put in place to cushion the negative income shock for this part of the population. We return to these two points in the conclusion.

\subsection{Impact on income poverty and inequality}

This section now turns to the effects of COVID-19 on income poverty and inequality. We start by comparing poverty and inequality indicators in the pre-COVID baseline with those under the COVID scenario. Then, we decompose the total change in income poverty and inequality into the contribution of COVID-related policies (policy effects) and other effects. Poverty and inequality are measured at the individual level, based on per capita household disposable income.

The left-hand side (first three columns) of Table 2 present income inequality and poverty indicators under the pre-COVID scenario (A), the COVID scenario (B), and the total change between the two ((A)-(B)). Our results show that the COVID-19 pandemic and lockdown measures lead to a significant and sharp increase in poverty and inequality in Ecuador. Inequality measured by the Gini coefficient increases from 0.461 to 0.592 , whereas the Theil index increases from 0.395 to 0.601 . 
Table 2: Decomposing the change in income inequality and poverty.

\begin{tabular}{|c|c|c|c|c|c|}
\hline & \multirow{2}{*}{$\begin{array}{c}\text { Pre-COVID } \\
\text { scenario } \\
\text { (A) }\end{array}$} & \multirow{2}{*}{$\begin{array}{l}\text { COVID } \\
\text { scenario } \\
\text { (B) }\end{array}$} & \multirow{2}{*}{$\begin{array}{l}\text { Total } \\
\text { change } \\
(B)-(A)\end{array}$} & \multicolumn{2}{|c|}{ Decomposition of total change } \\
\hline & & & & $\begin{array}{l}\text { COVID-related } \\
\text { policies effects }\end{array}$ & $\begin{array}{l}\text { Other } \\
\text { effects }\end{array}$ \\
\hline \multicolumn{6}{|l|}{ Inequality } \\
\hline Gini & 0.461 & 0.592 & $.131^{\star \star \star}$ & $-.011^{\star \star \star}$ & $.142^{\star \star \star}$ \\
\hline Theil & 0.395 & 0.601 & $.206^{\star \star \star}$ & $-.013^{\star \star \star}$ & 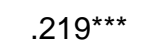 \\
\hline \multicolumn{6}{|l|}{ Poverty } \\
\hline FGTO (\%) & 25.672 & 58.224 & $32.552^{\star \star \star}$ & $-.640^{\star \star \star}$ & $33.192^{\star \star \star}$ \\
\hline FGT1 (\%) & 9.626 & 34.062 & $24.436^{\star \star \star}$ & $-1.567^{\star \star \star}$ & $26.002^{\star \star \star}$ \\
\hline \multicolumn{6}{|c|}{ Extreme poverty } \\
\hline FGTO (\%) & 9.235 & 38.626 & $29.391^{\star \star \star}$ & $-1.402^{\star \star \star}$ & 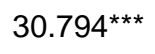 \\
\hline FGT1 (\%) & 3.579 & 22.22 & $18.641^{\star \star \star}$ & $-1.915^{\star \star \star}$ & $20.556^{\star \star \star}$ \\
\hline
\end{tabular}

Note: poverty and inequality indicators are based on per capita household disposable income. The 2019 national poverty lines of US\$85.03 per month for poverty and US\$47.92 per month for extreme poverty are used in the calculations. Statistical significance based on bootstrapped standard errors after 200 replications. Significance levels indicated as * $p<0: 1,{ }^{*} p<0: 05,{ }^{* *} p<0: 01$.

Source: authors' elaboration using ECUAMOD v1.5 and ENEMDU 2019 (INEC 2019).

In terms of poverty, the impact of the crisis is also large. Table 2 compares statistics on absolute poverty and extreme poverty headcounts (FGT0) and gaps (FGT1). The 2019 national poverty lines of US $\$ 85.03$ per month for poverty and US $\$ 47.92$ per month for extreme poverty are used in the calculations. ${ }^{16}$ Our results show a dramatic effect of the COVID-19 pandemic on poverty. As a result of the crisis, the poverty headcount increases substantially by 32.5 percentage points, meaning that 58.2 per cent of the population are below the national poverty line in May/June 2020 compared to 25.7 per cent in December 2019. Extreme poverty also increases strikingly, by 29.4 percentage points (from 9.2 to 38.6 per cent). Significant and sharp increases are also observed in terms of the (extreme) poverty gap, which increases from 9.6 (3.6) per cent to 34.1 (22.2) per cent.

The right-hand side (last two columns) of Table 2 presents the results of decomposing the total change in inequality and poverty into the effect of COVID-related policies and the 'other effects'. The latter includes all the factors not related to changes in policies between the pre-COVID and COVID scenarios, notably changes in the distribution of earnings (i.e. earning losses) but also automatic stabilizers and a non-zero residual term because the poverty and inequality indicators are non-additively decomposable. Our analysis shows that the 'other effects' explain most of the total change in disposable income inequality, contributing to a 0.142 increase in the Gini coefficient and 0.219 increase in the Theil index. COVID-related policies play a minor but significant role in

\footnotetext{
16 The extreme poverty line in Ecuador is defined in terms of the minimum value of a food consumption basket to satisfy the nutritional needs for a healthy life. The poverty line is then obtained by using the inverse of the Engel coefficient (which measures the relationship between expenditure in food consumption and expenditure in total consumption) to scale the extreme poverty line (INEC 2015).
} 
mitigating the effect of earnings losses on income inequality, accounting for a 0.011 point decrease in the Gini coefficient and a 0.013 decrease in the Theil index.

The total change in disposable income poverty (FGT0 and FGT1) also mostly reflects the contribution of the 'other effects', which account for an increase in the (extreme) poverty headcount of 33.2 (30.8) percentage points and an increase in the (extreme) poverty gap of 26 (20.6) percentage points. The COVID-related Family Protection Grant decreases poverty only modestly. It reduces the (extreme) poverty headcount by 0.64 (1.4) percentage points and has a larger effect on the (extreme) poverty gap, accounting for a reduction of 1.6 (1.9) percentage points.

\subsection{Disentangling the effect of changes at the 'extensive' and 'intensive' margins}

In our analysis, changes in household disposable income, poverty, and inequality are the result of two factors considered under our COVID scenario. At the 'extensive' margin, some individuals lose their jobs or experience a full loss in earnings (see Figure 1 and Figure 2). At the 'intensive' margin, formal and informal earners experience a cut to their earnings as a result of the crisis (see Table 1). The results presented in the previous sections reflect the sum of these two margins. In this section, we show the effect of accounting only for changes at the extensive margin and contrast it to the total effect.

Figure A1 in the Appendix repeats the decomposition analysis shown in Figure 3 for the percentage change in mean disposable income, but now accounting for changes at the extensive margin only. Figure A1 also shows the total change (extensive + intensive margin) in mean disposable income. The difference between the total change (red diamond) and the extensive margin change (white circle) gives the contribution of changes at the intensive margin. Our results show that, on average, household disposable income (white circle) drops by 29.5 per cent, meaning that changes at the extensive margin account for 72 per cent of the total reduction in mean disposable income, i.e. when both margins are considered (red diamond). The change in mean disposable income across the distribution is U-shaped for both the extensive margin change and the total change, while changes at the intensive margin account for a broadly uniform reduction in mean disposable income of 10 to 15 per cent throughout the distribution.

Losses in earnings (dark grey bar in Figure A1) accounting for the extensive margin only translate to a 31.6 per cent reduction in disposable income, on average, compared to 43.8 per cent when both margins are considered (dark grey bar in Figure 3). In terms of tax-benefit policies, accounting only for the extensive margin also reduces the role of automatic stabilizers as less people experience a change to their earnings. In comparison, the role of the Family Protection Grant remains broadly unchanged because, by design, the number of beneficiaries of the transfer is fixed and targets households at the bottom of the income distribution.

Finally, Table A3 in the Appendix repeats the analysis shown in Table 2 for poverty and inequality under the scenario accounting for changes at the extensive margin only. The results show that increased unemployment and full earning losses (i.e. the extensive margin) due to the COVID-19 pandemic account for the main increase in poverty and inequality. Accounting only for changes at the extensive margin, inequality measured by the Gini coefficient amounts to 0.573 , representing 97 per cent of the total increase in the Gini coefficient when both margins are considered. In terms of poverty, changes at the extensive margin account for around 80 per cent of the total increase in poverty. For instance, the extensive margin accounts for a 22.7 percentage points increase in the poverty headcount compared to the pre-COVID scenario (total change in Table A3), and the intensive margin accounts for an additional increase of 9.9 percentage points (difference in total change between Table 2 and Table A3). 
In response to the COVID-19 outbreak, Latin American governments implemented lockdown measures and adopted a variety of policies aimed at mitigating the adverse effect of the economic shock on household income. However, unlike in developed economies, countries in Latin America lack fiscal capacity to implement large income protection programmes. Moreover, some countries in the region were already facing challenging economic conditions because of low commodity prices prior to the pandemic. This was the case for Ecuador, which has been hit hard by the sanitary crisis and lacks fiscal space to strengthen social protection.

This study presents an assessment of the distributional impact of the COVID-19 pandemic and the role of government policy interventions in mitigating the socioeconomic effects of the crisis in Ecuador during the second quarter of 2020. More precisely, we compare the pre-COVID situation based on household survey data from December 2019 with a COVID scenario, derived by adjusting the 2019 data to reflect the effect of the pandemic on the labour market and earnings, based on household survey data collected by the National Statistical Institute in May/June 2020. ECUAMOD, the tax-benefit microsimulation model for Ecuador, is then used to decompose the changes in the income distribution and quantify the effects of: (i) earnings losses due to COVID19 , (ii) pre-crisis tax-benefit policies (i.e. automatic stabilizers), and (iii) COVID-related emergency measures implemented by the government.

Our analysis shows that household disposable income dropped dramatically by 41 per cent on average in May/June 2020 compared to December 2019. In line with recent findings for selected Latin American countries by Lustig et al. (2020), our results show that the impact of the pandemic is larger in the middle of the income distribution with a U-shaped pattern in the change of mean household disposable income. The COVID-19 pandemic has increased poverty and inequality significantly and sharply, with limited income protection provided by the Family Protection Grant introduced by the Ecuadorian government. Poverty has increased from 25.7 to 58.2 per cent, extreme poverty from 9.2 to 38.6 per cent, and the Gini coefficient has increased from 0.461 to 0.592. Our decomposition shows that the total effect of automatic stabilizers on household disposable incomes is larger than that of COVID-related benefits but with heterogenous effects across the income distribution. Moreover, our results highlight the modest role of benefits as automatic stabilizers in Ecuador. The latter is related to two factors. First, the design of the Human Development Transfer, the main social protection scheme in Ecuador, as a proxy means-tested benefit prevents it from acting as an automatic stabilizer in the event of employment or earnings shocks, as eligibility is based on a composite index capturing information about household characteristics and housing conditions. Second, the Unemployment Insurance benefit provides protection in the event of unemployment only to individuals affiliated to social security, leaving all workers in informal employment unprotected. Additionally, our analysis highlights that the losses in household incomes and the increase in poverty and inequality are mostly due to the increase in unemployment or full earnings losses (changes at the extensive margin) rather than earnings cuts (changes at the intensive margin).

From a policy perspective, our study highlights the importance of strengthening the role of the COVID-related emergency measures in Ecuador which have not managed to offset the adverse effect of the crisis at the bottom of the income distribution and have provided no protection to the middle class, which has been severely affected by the pandemic. In this sense, the results support the need to rethink and enhance social protection in Ecuador and the region. In particular, the lack of benefits acting as automatic stabilizers is a limitation of many countries in the region that rely on proxy means-tested benefits as the main schemes for social protection. Redesigning social protection should go hand in hand with efforts to build fiscal capacity in order to ensure the 
sustainability of social policies in the long term. Progressive personal income tax reforms, which could raise additional tax revenues, would ensure higher government resources to invest in social protection and reduce inequality (Deza et al. 2020). Fiscal reforms should, however, not be restricted to personal income tax. Reforms to corporate and wealth taxes should also be considered, with the aim of increasing fiscal capacity to finance sustainable welfare and healthcare systems.

Finally, it is important to acknowledge that the analysis does not account for other mitigation strategies, such as inter-household transfers, which people may be relying on during the crisis. The analysis focuses on the protection provided by government policies and the results may thus provide a partial picture of the increase in income disparities.

\section{References}

Adams-Prassl, A., T. Boneva, M. Golin, and C. Rauh (2020). 'Inequality in the Impact of the Coronavirus Shock: Evidence from Real Time Surveys'. Journal of Public Economics, 189: 104245. https://doi.org/10.1016/j.jpubeco.2020.104245.

Altamirano, A., O. Azuara, and S. González (2020). ‘Cómo Impactará la COVID-19 al Empleo?: Posibles Escenarios Para América Latina y el Caribe'. Políticas Sociales en Respuesta al Coronavirus. Washington, DC: IDB.

ANDA (2012). 'Encuesta Nacional de Ingresos y Gastos de los Hogares Urbanos y Rurales. 2011-2012' ('National Survey of Income and Expenditure of Urban and Rural Households. 2011-2012'). [Spanish only]. Guayaquil: Instituto Nacional de Estadistica y Censos. Archivo Nacional de Datos y Metadatos Estadísticos. Available at:

http://anda.inec.gob.ec/anda/index.php/catalog/291\#page=overview\&tab=study-desc (accessed December 2020).

Asamblea Nacional (2020). 'Ley Orgánica de Apoyo Humanitario para Combatir la Crisis Sanitaria derivada del Covid-19' ('Organic Law of Humanitarian Support to Fight the COVID-19 Sanitary Crisis'). [Spanish only]. Official Registry No. 229. 22 June. Ecuador: Government of Ecuador.

Bargain, O., and T. Callan (2010). 'Analysing the Effects of Tax-Benefit Reforms on Income Distribution: A Decomposition Approach'. Journal of Economic Inequality, 8(1): 1-21. https://doi.org/10.1007/s10888-008-9101-4

Bargain, O., H.X. Jara, and D. Rodríguez (2017). 'Learning from Your Neighbor: Swapping Tax-Benefit Systems in Latin America'. Journal of Economic Inequality, 15(4): 369-392.

https://doi.org/10.1007/s10888-017-9367-5

Beirne, K., K. Doorley, M. Regan, B. Roantree, and D. Tuda (2020). 'The Potential Costs and Distributional Effect of Covid-19 Related Unemployment in Ireland'. EUROMOD Working Paper EM05/20. Colchester: University of Essex.

Béland, L.-P., A. Brodeur, and T. Wright (2020). 'The Short-term Economic Consequences of Covid-19: Exposure to Disease, Remote Work and Government Response'. IZA Discussion Paper 13159. Bonn: IZA.

Bonavida, C., and L. Gasparini (2020). 'El Impacto Asimétrico de la Cuarentena'. Documento de Trabajo 261. La Plata: CEDLAS, Universidad Nacional de La Plata.

Bottan N, B. Hoffmann, and D. Vera-Cossio (2020). 'The Unequal Impact of the Coronavirus Pandemic: Evidence from Seventeen Developing Countries'. PLOS ONE, 15(10): e0239797. https://doi.org/10.1371/journal.pone.0239797

Brewer, M., and I. Tasseva (2020). 'Did the UK Policy Response to Covid-19 Protect Household Incomes?'. EUROMOD Working Paper EM12/20. Colchester: University of Essex. 
Bronka, P., D. Collado, and M. Richiardi (2020). 'The Covid-19 Crisis Response Helps the Poor: The Distributional and Budgetary Consequences of the UK Lock-down'. EUROMOD Working Paper EM11/20. Colchester: University of Essex.

Burn-Murdoch, J., V. Romei, and C. Giles (2020). 'Global Coronavirus Death Toll Could be 60\% Higher than Reported'. Financial Times, 26 April. Available at: https:/ /www.ft.com/content/6bd88b7d-33864543-b2e9-0d5c6fac846c (accessed 17 December 2020).

Daude, C., Á. Melguizo, and A. Neut (2011) 'Fiscal Policy in Latin America: Countercyclical and Sustainable?'. Economics: The Open-Access, Open-Assessment E-Journal, 5: 2011-14. https://doi.org/10.5018/economics-ejournal.ja.2011-14

Decoster, A., J. Pirttilä, H. Sutherland, and G. Wright. (2019). 'SOUTHMOD: Modelling Tax-Benefit Systems in Developing Countries'. International Journal of Microsimulation, 12(1): 1-12.

Deza, M.C., H.X. Jara, N. Oliva, and J. Torres (2020). 'Simulating Personal Income Tax Reforms in the Andean Region'. IADB Technical Note. IDB-TN- 195 7. Washington, DC: IADB.

DNRCIC (Dirección Nacional de Registro Civil, Identificación y Cedulación) (2020). 'Matriz-defuncionesactualizada 30 de junio 2020'. [Spanish only]. Available at: https://www.registrocivil.gob.ec/wpcontent/uploads/downloads/2020/07/Matriz-defunciones-actualizada-30-de-junio-2020.pdf (accessed October 2020)

ECLAC (2019). 'Social Panorama of Latin America, 2019'. LC/PUB.2019/22-P/Rev.1. Santiago: ECLAC.

ECLAC (2020a). 'Sectores y Empresas Frente al COVID-19: Emergencia Y Reactivación'. Informe especial 4. Covid-19. Santiago de Chile: ECLAC.

ECLAC (2020b). 'Addressing the Growing Impact of COVID-19 with a View to Reactivation with Equality: New Projections'. Santiago de Chile: ECLAC.

Espino, E., and M. González Rozada (2012). 'Automatic Stabilization and Fiscal Policy: Some Quantitative Implications for Latin America and the Caribbean'. IDB Working Paper, 367. Washington, DC: IDB.

FAO (2020). Impact of Covid-19 on Informal Workers. Rome: Food and Agriculture Organization of the United Nations.

Figari, F., and C.V. Fiorio (2020). 'The Resilience of the Italian Social Protection System at the Beginning of COVID-19 Outbreak: Territorial Evidence'. Politica Economica, 36(1): 3-34.

Gupta, S., L. Montenovo, T.D. Nguyen, F.L. Rojas, I.M. Schmutte, K.I. Simon, B.A. Weinberg, and C. Wing (2020). 'Effects of Social Distancing Policy on Labor Market Outcomes'. Working Paper 27280. Working Paper Series. Cambridge, MA: National Bureau of Economic Research. https://doi.org/10.3386/w27280

INEC (Instituto de Estadísticas y Censos) (2015). Metodología de construcción del agregado del consumo y estimación de linea de pobreza en el Ecuador. Quito: INEC.

INEC (Instituto de Estadísticas y Censos) (2019). 'Encuesta Nacional de Empleo, Desempleo y Subempleo. ENEMDU - diciembre 2019' ('National Survey of Employment, Unemployment and Underemployment (ENEMDU)'). [Spanish only]. Available at:

https://www.ecuadorencifras.gob.ec/enemdu-diciembre-2019/(accessed December 2020).

INEC (Instituto de Estadísticas y Censos) (2020a). 'COVID-19 Afecta publicación ENEMDU'. Comunicado Oficial Available at: https://www.ecuadorencifras.gob.ec/institucional/covid-19afecta-publicacion-enemdu/_(accessed June 2020)

INEC (Instituto de Estadísticas y Censos) (2020b). 'Encuesta Nacional de Empleo, Desempleo y Subempleo. ENEMDU Telefonica' ('National Survey of Employment, Unemployment and Underemployment (ENEMDU)'). [Spanish only]. Available at: https://www.ecuadorencifras.gob.ec/enemdu-telefonica/ (accessed December 2020).

Jara, H.X. (2018). 'Unemployment Insurance and Income Protection in Ecuador'. WIDER Working Paper 2018/151. Helsinki: UNU-WIDER. https://doi.org/10.35188/UNU-WIDER/2018/593-0 
Jara, H.X., and L. Montesdeoca (2020). SOUTHMOD Country Report Ecuador-ECUAMOD V1.5. Helsinki: UNU-WIDER.

Jara, H.X., and M. Varela. (2019). 'Tax-Benefit Microsimulation and Income Redistribution in Ecuador'. International Journal of Microsimulation, 12(1): 52-82.

Jouste, M., and P. Rattenhuber (2019). 'A Role for Universal Pension? Simulating Universal Pensions in Ecuador, Ghana, Tanzania and South Africa'. International Journal of Microsimulation, 12(1): 13-51.

Li, J., and C. O’Donoghue (2014). 'Evaluating Binary Alignment Methods in Microsimulation Models'. Journal of Artifical Societies and Social Simulation, 17(1): art. 15. https://doi.org/10.34196/ijm.00194

Lustig, N., V.M. Pabon, F. Sanz, and S.D. Younger (2020). 'The Impact of COVID-19 Lockdowns and Expanded Social Assistance on Inequality, Poverty and Mobility in Argentina, Brazil, Colombia and Mexico'. CEQ Working Paper 92. New Orleans, LA: CEQ Institute, Tulane University.

Martorano, B. (2018). 'Cyclicality of Fiscal Policy in Latin America Over the Period 1990-2015'. Review of Development Economics, 22(1): 67-90. https:// doi.org/10.1111/rode.12329

OECD (2019). Society at a Glance 2019: OECD Social Indicators. Paris: OECD Publishing. https://doi.org/10.1787/soc_glance-2019-en

OECD et al. (2020). Revenue Statistics in Latin America and the Caribbean 2020. Paris: OECD Publishing. https://doi.org/10.1787/24104736

Paulus, A., and I. Tasseva (2020). 'Europe Through the Crisis: Discretionary Policy Changes and Automatic Stabilisers'. Oxford Bulletin of Economics and Statistics, 82(4): 864-88. https://doi.org/10.1111/obes.12354.

Presidencia de la República (2020a). 'Decreto Ejecutivo No. 1022' ('Executive Decree 1022'). [Spanish only]. Official Registry No 173. 27 March. Ecuador: Government of Ecuador

Presidencia de la República (2020b). 'Decreto Ejecutivo No. 1026' ('Executive Decree 1026'). [Spanish only]. Official Registry. 24 April. Ecuador: Government of Ecuador.

Presidencia de la República (2020c) 'Decreto 1053. Cambio en la Ley Orgánica del Servicio Público para la Reducción en la jornada de trabajo de hasta 30 horas a la semana'. [Spanish only]. 19 May. Ecuador: Government of Ecuador.

Sumner, A., E. Ortiz-Juarez, and C. Hoy (2020). 'Precarity and the Pandemic: Covid-19 and Poverty Incidence, Intensity, and Severity in Developing Countries'. WIDER Working Paper 2020/77. Helsinki: UNU-WIDER. https:/ / doi.org/10.35188/UNU-WIDER/2020/834-4

Sutherland, H., and F. Figari (2013). 'EUROMOD: 'The European Union Tax-Benefit Microsimulation Model'. International Journal of Microsimulation, 1(6): 4-26.

Vegh, C.A., G. Vuletin, D. Riera-Crichton, J. Puig, J.A. Camarena, L. Galeano, L., Morano, and L.Venturi (2019). 'Effects of the Business Cycle on Social Indicators in Latin America and the Caribbean: When Dreams Meet Reality'. LAC Semiannual Report. Washington, DC: World Bank.

WHO (2020). 'Coronavirus Disease (COVID-19) Dashboard'. Downloaded from: https:// covid19. who.int/?gclid=Cj0KCQjw3Nv3BRC8ARIsAPh8hgLKAtb43r1bLJtvQ842muzbTr 39MHVww6ZMYX2VqzSQx0WmZFA89QwaAuhaEALw_wcB (Date: 8:18 am CEST, 27 June 2020). 


\section{Appendix}

Table A1: Probit estimation of the probability of being unemployed in 2020

\begin{tabular}{lcc}
\hline & Coef. & St. error \\
Constant & $0.465^{\star \star}$ & $(0.211)$ \\
Age & $-0.0624^{\star \star \star}$ & $(0.00717)$ \\
Age $^{2}$ & $0.000546^{\star \star \star}$ & $(8.12 \mathrm{e}-05)$ \\
Married & $-0.247^{\star \star \star}$ & $(0.0460)$ \\
Low education & 0.117 & $(0.161)$ \\
Middle education & $0.295^{\star}$ & $(0.162)$ \\
High education & $0.310^{\star}$ & $(0.165)$ \\
Rural area & $-0.497^{\star \star \star}$ & $(0.0451)$ \\
Female & $0.759^{\star \star}$ & $(0.335)$ \\
$\quad$ x Age & -0.00318 & $(0.0120)$ \\
$\quad$ x Age & \\
$\quad$ x Married & -0.000121 & $(0.000139)$ \\
$\quad$ x Low education & -0.0279 & $(0.0697)$ \\
$\quad$ x Middle education & 0.0442 & $(0.246)$ \\
$\quad$ x High education & -0.0695 & $(0.249)$ \\
x Rural area & $-0.485^{\star}$ & $(0.253)$ \\
Number of observations & 0.0912 & $(0.0705)$ \\
\hline
\end{tabular}

Note: the dependent variable is one if the person is unemployed, zero otherwise. The model is estimated on the sample of individuals in work or unemployment. Standard errors are shown in parenthesis. Significance levels indicated as * $p<0.1,{ }^{* *} p<0.05$, *** $p<0.01$.

Source: authors' elaboration based on ENEMDU 2020 (INEC 2020b). 
Table A2: Sample characteristics of the original and adjusted microdata

\begin{tabular}{|c|c|c|c|c|c|c|}
\hline & \multicolumn{2}{|c|}{ ENEMDU 2019} & \multicolumn{2}{|c|}{ ENEMDU 2020} & \multicolumn{2}{|c|}{ ENEMDU 2019 adjusted } \\
\hline & $\begin{array}{l}\text { Formal } \\
\text { earner }\end{array}$ & $\begin{array}{l}\text { Informal } \\
\text { earner }\end{array}$ & $\begin{array}{l}\text { Formal } \\
\text { earner }\end{array}$ & $\begin{array}{l}\text { Informal } \\
\text { earner }\end{array}$ & $\begin{array}{l}\text { Formal } \\
\text { earner }\end{array}$ & $\begin{array}{l}\text { Informal } \\
\text { earner }\end{array}$ \\
\hline Male & 60.9 & 64.1 & 62.7 & 67.1 & 62.6 & 68.8 \\
\hline Female & 39.1 & 35.9 & 37.3 & 32.9 & 37.4 & 31.2 \\
\hline \multicolumn{7}{|l|}{ Education: } \\
\hline Primary or lower & 31.7 & 57.0 & 28.2 & 52.2 & 29.5 & 59.0 \\
\hline Secondary & 34.4 & 33.7 & 36.6 & 38.1 & 35.9 & 33.0 \\
\hline Tertiary & 33.9 & 9.3 & 35.3 & 9.7 & 34.7 & 8.0 \\
\hline \multicolumn{7}{|l|}{ Employment status: } \\
\hline Employee & 76.5 & 40.3 & 77.9 & 35.5 & 73.7 & 36.6 \\
\hline Self-employed & 23.5 & 59.7 & 22.1 & 64.5 & 26.3 & 63.4 \\
\hline
\end{tabular}

Source: authors' elaboration based on ENEMDU 2019 (INEC 2019) and ENEMDU 2020 (INEC 2020b).

Table A3: Decomposing the change in income inequality and poverty-extensive margin changes only

\begin{tabular}{|c|c|c|c|c|c|}
\hline & \multirow{2}{*}{$\begin{array}{c}\text { Pre-COVID } \\
\text { scenario } \\
\text { (A) }\end{array}$} & \multirow{2}{*}{$\begin{array}{l}\text { COVID } \\
\text { scenario } \\
\text { (B) }\end{array}$} & \multirow{2}{*}{$\begin{array}{l}\text { Total } \\
\text { change } \\
(B)-(A)\end{array}$} & \multicolumn{2}{|c|}{ Decomposition of total change } \\
\hline & & & & $\begin{array}{l}\text { COVID-related } \\
\text { policies effects }\end{array}$ & $\begin{array}{l}\text { Other } \\
\text { effects }\end{array}$ \\
\hline \multicolumn{6}{|l|}{ Inequality } \\
\hline Gini & 0.461 & 0.573 & $.112^{\star \star *}$ & $-.009 * \star \star$ & $.121^{\star \star \star}$ \\
\hline Theil & 0.395 & 0.563 & $.168^{\star \star \star}$ & $-.008^{\star \star \star}$ & $.176^{\star \star \star}$ \\
\hline \multicolumn{6}{|l|}{ Poverty } \\
\hline FGTO (\%) & 25.672 & 48.354 & $22.682^{\star \star \star}$ & $-.867^{\star \star \star}$ & 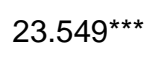 \\
\hline FGT1 (\%) & 9.626 & 28.449 & $18.823^{\star \star \star}$ & $-1.352^{\star \star \star}$ & $20.176^{\star \star \star}$ \\
\hline \multicolumn{6}{|c|}{ Extreme poverty } \\
\hline FGTO (\%) & 9.235 & 30.777 & $21.542^{\star \star \star}$ & 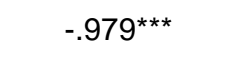 & $22.522^{\star \star \star}$ \\
\hline FGT1 $(\%)$ & 3.579 & 19.197 & $15.618^{\star \star \star}$ & $-1.607^{\star \star \star}$ & $17.225^{\star \star \star}$ \\
\hline
\end{tabular}

Notes: poverty and inequality indicators are based on per capita household disposable income. The 2019 national poverty lines of US $\$ 85.03$ per month for poverty and US $\$ 47.92$ per month for extreme poverty are used in the calculations. Statistical significance based on bootstrapped standard errors after 200 replications. Significance levels indicated as * $p<0: 1,{ }^{* *} p<0: 05$, ${ }^{* \star} p<0: 01$.

Source: authors' elaboration using ECUAMOD v1.5 and ENEMDU 2019 (INEC 2019). 
Figure A1: Change in mean disposable income by income decile-extensive margin changes only

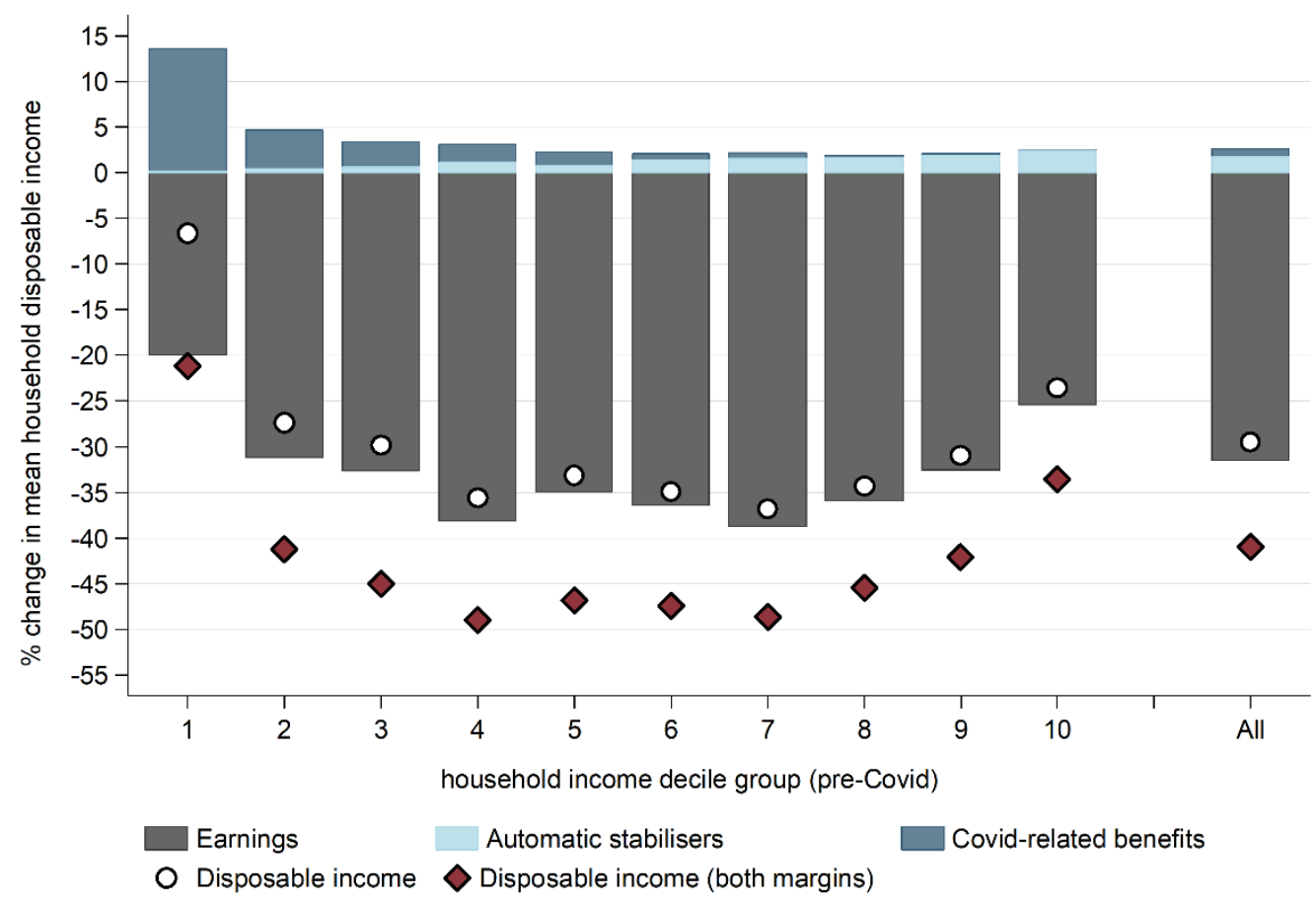

Note: the figure shows the distributional impact of the employment and earnings shocks and the policy response from the Ecuadorian government, i.e. the pre-COVID versus the COVID scenario. Changes in income are based on per capita household disposable income.

Source: authors' elaboration using ECUAMOD v1.5 and ENEMDU 2019 (INEC 2019). 